\title{
2. The World Economy
}

\section{Turkey: Trade Policy Review, 2007}

\author{
Sübidey Togan \\ Bilkent University, Ankara
}

\section{INTRODUCTION}

\begin{abstract}
$\mathcal{U}$ HE Trade Policy Review: Turkey 2007, the fourth of its kind, provides a comprehensive survey of trade policy developments and practices in Turkey. The review brings together a considerable amount of information on trade and tariff structures, exports, sector and trade-related policies in Turkey. This paper examines the status of Turkey's trade policy regime following the approach of the Trade Policy Review: Turkey 2007. As highlighted in the paper Turkey is pursuing a strategy of trade liberalisation through negotiations at the multilateral, regional and bilateral levels. As of 2009 tariffs in Turkey are a non-issue in the non-agricultural sector, but technical barriers to trade are still a major problem that hinders the attainment of free trade in industrial goods.

The paper is structured as follows. The next section of the paper describes the main developments in Turkey's trade regime and the third section considers the Turkish trade performance. Section 4 examines the trade policy under the headings of measures affecting imports, exports and foreign direct investment. The fifth section discusses technical barriers to trade, and the sixth and final section offers conclusions.
\end{abstract}

\section{MAIN DEVELOPMENTS}

After pursuing inward-oriented development strategies for 50 years Turkey switched over to outward-oriented policies in 1980. The policy of further opening up the economy was pursued with the aim of integrating into the world economy through membership in the World Trade Organization (WTO) and close association with the European Union (EU).

Turkey, which became an original Member of the WTO on 26 March 1995, accords at least Most Favoured Nation (MFN) treatment to almost all WTO Members. Turkey is not a signatory to any of the plurilateral agreements that resulted from the Uruguay Round but is an observer in the Committees on Government 
Procurement and Trade in Civil Aircraft, and party to the Information Technology Agreement. Turkey attaches great importance to the Doha Development Agenda (DDA). Its main interests in the DDA are attaining a fair, competitive and predictable trading environment where trade-distorting support measures are eliminated. For Turkey, agriculture is the key issue of the DDA, and Turkey attaches utmost importance to non-agricultural market access negotiations and trade facilitation.

Turkey's application for association with the European Economic Community was made in 1959. The application ultimately resulted in the signing of the Association Agreement in 1963. The Additional Protocol to the Ankara Agreement was signed in 1970, and became effective in 1973. The basic aim of the Additional Protocol is the establishment of a customs union. In 1995 it was agreed at the Association Council meeting under Decision No. 1/95 (CUD) that Turkey would create a customs union with the EU starting on 1 January, 1996. According to CUD all industrial goods, except products of the European Coal and Steel Community (ECSC), that comply with the European Community (EC) norms could circulate freely between Turkey and the EU as of 1 January 1996. For ECSC products, Turkey signed a free trade agreement (FTA) with the EU in July 1996, and, as a result, ECSC products have received duty-free treatment between the parties since 1999. The CUD does cover processed agricultural products, but not the agricultural commodities and services.

In 1999 the Helsinki European Council recognised Turkey as a candidate for EU membership on equal footing with other potential candidates. In December 2002 the Copenhagen European Council decided that "the EU would open negotiations with Turkey "without delay" if the European Council in December 2004, on the basis of a report and a recommendation from the Commission, decides that Turkey fulfils the Copenhagen political criteria'. The EU leaders agreed on 16 December 2004 to start accession negotiations with Turkey from 3 October 2005. Right after the official launching of the EU accession negotiations the screening process started which lasted until October 2006. Thereafter the Commission prepared the screening reports for each of the 35 policy chapters. The first chapter to be negotiated, Chapter 25 on 'Science and Research', was opened and provisionally closed on 12 June 2006. In November 2006, the EU expressed concern over restrictions to the free movement of goods, including restrictions on means of transport to which Turkey had committed by signing the Additional Protocol to the Ankara Agreement. With no solution found, the European Council decided on 14-15 December 2006 to suspend negotiations on eight chapters relevant to Turkey's restrictions with regard to the Republic of Cyprus. ${ }^{1}$ It was also decided

\footnotetext{
${ }^{1}$ The eight chapters are: Chapter 1 on free movement of goods, Chapter 3 on the right of establishment and freedom to provide services; Chapter 9 on financial services; Chapter 11 on agriculture and rural development; Chapter 13 on fisheries; Chapter 14 on transport policy; Chapter 29 on customs unions; and Chapter 30 on external relations.
} 
that no chapter would be provisionally closed until Turkey fulfils its commitments under the additional protocol to the EU-Turkey Association Agreement. However, this did not mean that the process of negotiations was blocked. As of January 2007, the negotiations were back on track on the chapters that were not suspended. ${ }^{2}$

The CUD required Turkey to implement the EC's Common Customs Tariffs on imports of industrial goods from third countries as of 1 January 1996, to adopt by 2001 all of the preferential trade agreements the EU has concluded over time, and to implement on the commercial policy side measures similar to those of the European Community's commercial policy. As a result Turkey signed FTAs with the European Free Trade Association countries, Israel, Macedonia, Croatia, Bosnia-Herzegovina, Palestinian Authority, Tunisia, Morocco, Syria, Egypt, Albania and Georgia. Under these agreements, bilateral trade was to be liberalised on industrial goods at the end of a transition period, and mutual concessions were granted on selected agricultural and processed agricultural goods. ${ }^{3}$ As part of the CUD, Turkey has based its Generalised System of Preferences (GSP) on the EC's. Under Turkey's GSP regime, preferences are granted to selected nonagricultural goods, including raw materials and semi-finished goods. On the commercial policy side Turkey has adopted EC competition law, established the Competition Board, adopted the EC rules on protection of intellectual and industrial property rights, and established the Patent Office.

In addition to its trade relations with the EC, Turkey also participates in the Economic Cooperation Organisation (ECO), the Black Sea Economic Cooperation (BSEC), and in the Euro-Mediterranean Partnership, a political, economic and social programme aimed at creating an area of shared prosperity, including a Euro-Mediterranean Free Trade Area by $2010 .{ }^{4}$

\footnotetext{
${ }^{2}$ Chapter 20 on 'Enterprise and Industrial Policy' was opened for negotiation at the end of March 2007, and two more negotiation chapters were opened thereafter, namely Chapter 18 on 'Statistics' and Chapter 32 on 'Financial Control' at the end of March 2007. At the end of December 2007 Chapter 21 on 'Trans-European Networks' and Chapter 28 on 'Health and Consumer Protection', and during June 2008 Chapter 6 on 'Company Law' and Chapter 7 on 'Intellectual Property' were opened. Lately, with the opening of Chapter 4 on 'Free Movement of Capital' and Chapter 10 on 'Information Society and Media' the number of policy chapters opened has increased to 10.

${ }^{3}$ Negotiations are in progress with the Faroe Islands, Gulf Cooperation Council, Jordan, Lebanon and Montenegro, while exploratory talks have been held with Chile, Mexico, the Southern African Customs Union and Ukraine.

${ }^{4}$ The ECO is an inter-governmental regional organisation established in 1985 by Iran, Pakistan and Turkey for the purpose of sustainable socio-economic development of member states. In 1992, the Organisation was expanded to include Afghanistan, Azerbaijan, Kazakhstan, the Kyrgyz Republic, Tajikistan, Turkmenistan and Uzbekistan. On 17 July 2003 the ECO Trade Agreement (ECOTA) was signed between Afghanistan, Iran, Pakistan, Tajikistan and Turkey. The Agreement foresees the reduction of tariffs to a maximum of 15 per cent within a maximum period of eight
} 


\section{TRADE PERFORMANCE AND INVESTMENT}

Until the early 1980s Turkey was a fairly closed economy. At that time - as part of more wide-ranging economic reforms - the trade policy of protection and import substitution was replaced by a much more open trade regime. As a result, exports and imports increased considerably over time. While Turkey's merchandise exports (imports) amounted to US\$2.9 (7.9) billion in 1980, they increased to US\$131.97 (201.96) billion in 2008. On the other hand, exports (imports) of goods and services increased during the same period from US $\$ 3.4$ (7.8) billion in 1980 to US\$187.2 (227.7) billion in 2008. This amounts to an average annual rate of growth of merchandise exports (imports) of 14.6 (12.3) per cent, and of exports (imports) of goods and services of 15.4 (12.8) per cent, respectively. As a per cent of GDP merchandise, exports (imports) increased from 4.5 (12.1) per cent in 1980 to 16.6 (25.4) per cent in 2008, and exports (imports) of goods and services from 5.2 (11.9) per cent in 1980 to 23.6 (28.7) per cent in 2008. These are remarkable increases by any standards achieved within the context of a liberal trade regime.

Kaminski and $\mathrm{Ng}$ (2007) note that countries take advantage of opportunities offered by global markets successfully as long as three conditions are satisfied: macroeconomic stability, contestable and competitive domestic markets that are open to external competition, and well-functioning backbone services. Although Turkey historically failed on the macroeconomic test, the condition seems to be satisfied after the stabilisation measures taken during and after 2001. On the other hand, the liberalisation measures taken during the 1980s, CUD and the EU accession process have contributed immensely to the emergence of contestable domestic markets and to improved efficiency in service sectors.

Table 1 shows that in 2008 exports to the EU15 formed 48.4 per cent of total exports. The table further reveals that the three export commodities with the highest shares in total exports were 'automotive products' with a share of 13.4 per cent, 'iron and steel' with a share of 12.6 per cent, and 'clothing' with a share of 10.2 per cent. The three export commodities with the highest shares in exports to the EU were 'automotive products' with a share of 20.8 per cent, 'clothing' with a share of 17.1 per cent, and 'other semi-manufactures' with a share of 7.9 per cent. During the period 1995-2008 total exports grew at an

years. ECOTA has binding provisions on state monopolies, state aid, protection of intellectual property rights, dumping and anti-dumping measures. On the other hand, the BSEC aims to improve and diversify economic and trade relations among its 11 members. The member countries are Albania, Armenia, Azerbaijan, Bulgaria, Georgia, Greece, Moldavia, Romania, the Russian Federation, Turkey and Ukraine. The BSEC Declaration was signed on 25 June 1992, and on 7 February 1997 a declaration of intent for the establishment of a BSEC free trade area was adopted. Recently, BSEC launched projects to eliminate non-tariff barriers on regional trade and to harmonise trade documents in the region. 
annual rate of 13.9 per cent. The export commodities with the highest annual growth rates were 'other products' with a growth rate of 41.9 per cent, 'automotive products' with a growth rate of 27.6 per cent, and 'other transport equipment' with a growth rate of 21.4 per cent. Similarly the export commodities to the EU with the highest growth rates were 'automotive products' with a growth rate of 32.8 per cent, 'other products' with a growth rate of 29.4 per cent, and 'office machines and equipment' with a growth rate of 20.8 per cent. Finally, we note that the share of the EU in total sectoral exports has been highest in the cases of 'office machines and telecommunications equipment' with a share of 85.5 per cent, 'clothing' with a share of 81.1 per cent, and 'automotive products' with a share of 75.2 per cent. Among the sectors considered the share of the EU in total sectoral exports has been the lowest in the cases of 'other products', 'iron and steel' and 'other chemicals'.

Table 2 shows that imports from the EU15 formed 37.2 per cent of total imports. The table further reveals that the three import commodities with the highest shares in total imports were 'fuels' with a share of 23.8 per cent, 'automotive products' with a share of 7.5 per cent, and 'iron and steel' with a share of 7.4 per cent. The three import commodities with the highest shares in imports from the EU were 'automotive products' with a share of 15.7 per cent, 'other non-electrical machinery' with a share of 12.7 per cent, and 'other semimanufactures' with a share of 7.0 per cent. During the period 1995-2008 total imports grew at an annual rate of 12.4 per cent. The imported commodities with the highest annual growth rates were 'other products' with a growth rate of 36.2 per cent, 'clothing' with a growth rate of 22.9 per cent, and 'non-ferrous metals' with a growth rate of 17.5 per cent. Similarly the imported commodities from the EU with the highest growth rates were 'fuels' with a growth rate of 18.9 per cent, 'pharmaceuticals' with a growth rate of 17.4 per cent, and 'automotive products' with a growth rate of 15.7 per cent. Finally, we note that the share of the EU in total sectoral imports has been highest in the cases of 'automotive products' with a share of 77.8 per cent, 'pharmaceuticals' with a share of 68.6 per cent, and 'other non-electrical machinery' with a share of 64.5 per cent. Among the sectors considered, the share of the EU in total sectoral imports has been the lowest in the cases of 'other products', 'fuels' and 'clothing'.

Turning to consideration of foreign direct investment (FDI) flows we note that Turkey until recently was not successful in attracting FDI inflows. Annual FDI inflows amounted to only US\$791 million during 1990-2000. The country's failure to attract large foreign investment inflows was mainly due to economic and political uncertainties surrounding the country in the 1990s and early 2000s, and the unfavourable investment climate in particular to foreign investors. With the introduction of the 2001 programme of economic stabilisation, implementation of its privatisation programme, the EU's 2004 decision to begin membership 


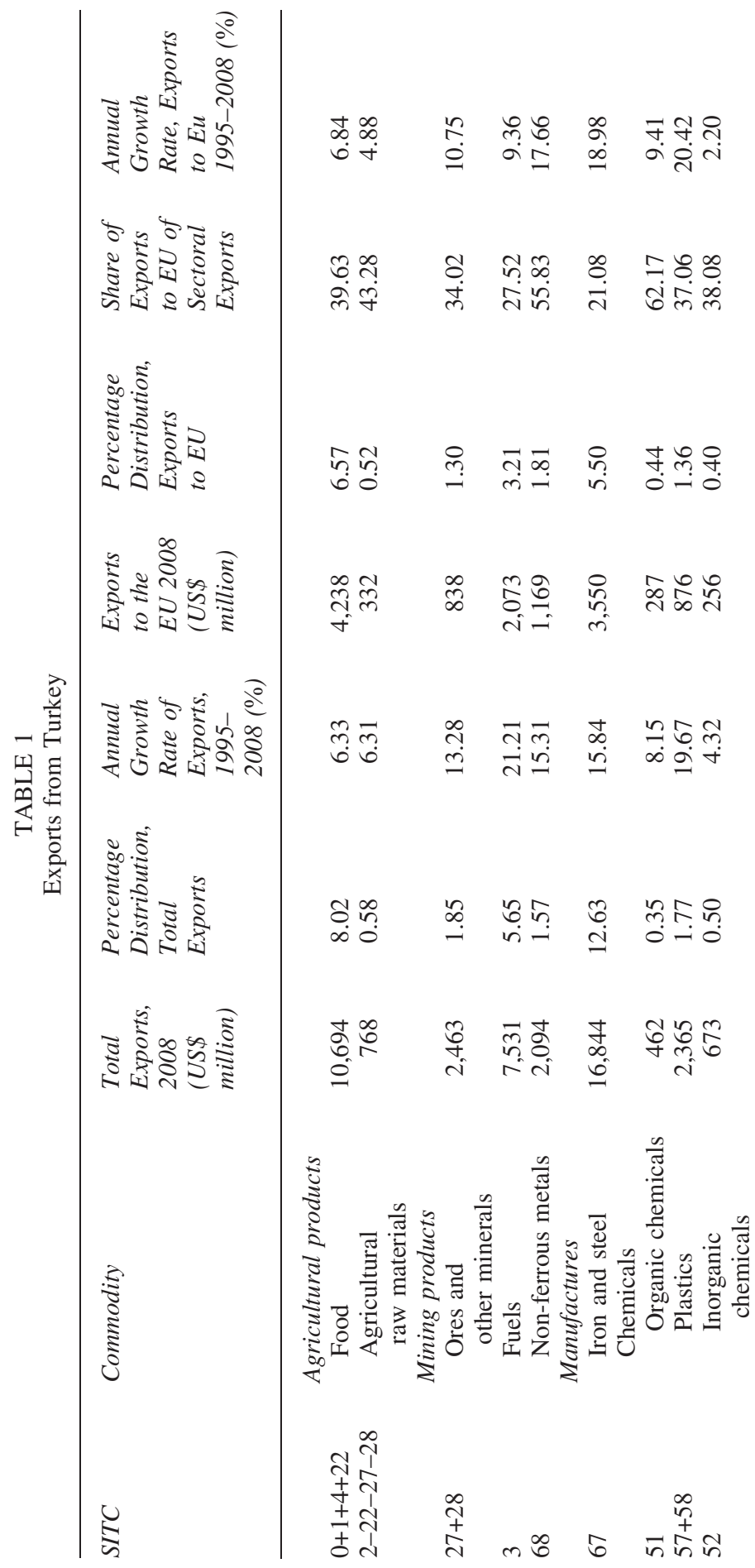




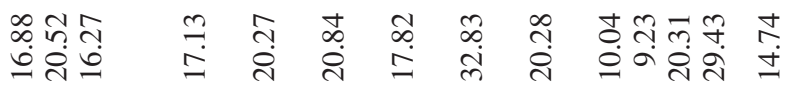

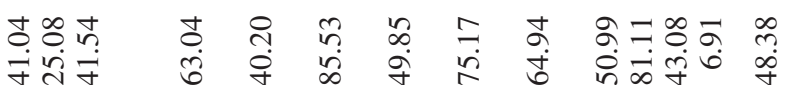

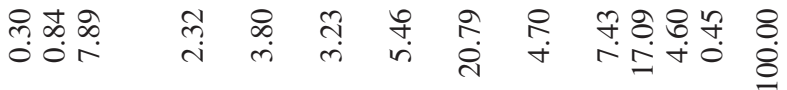

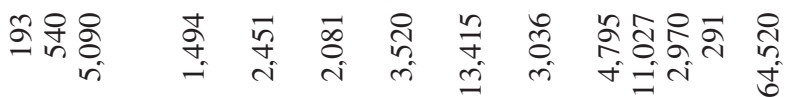

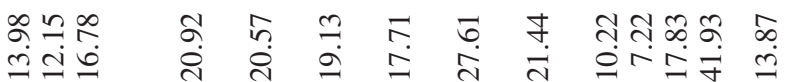
ஸेढ̆

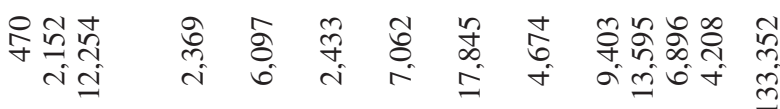
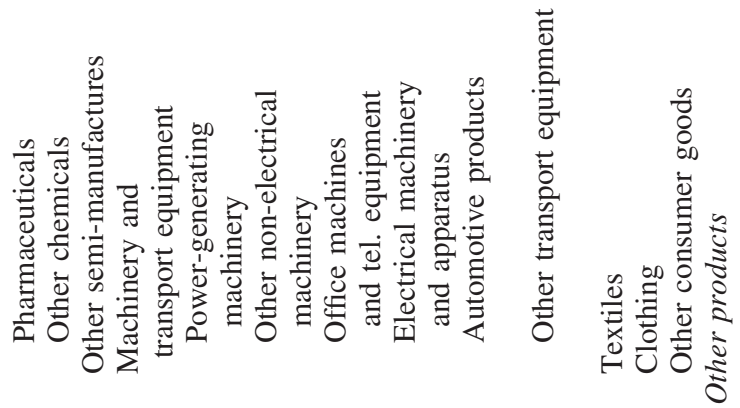

$$
\stackrel{\text { 过 }}{\dot{\Xi}}
$$




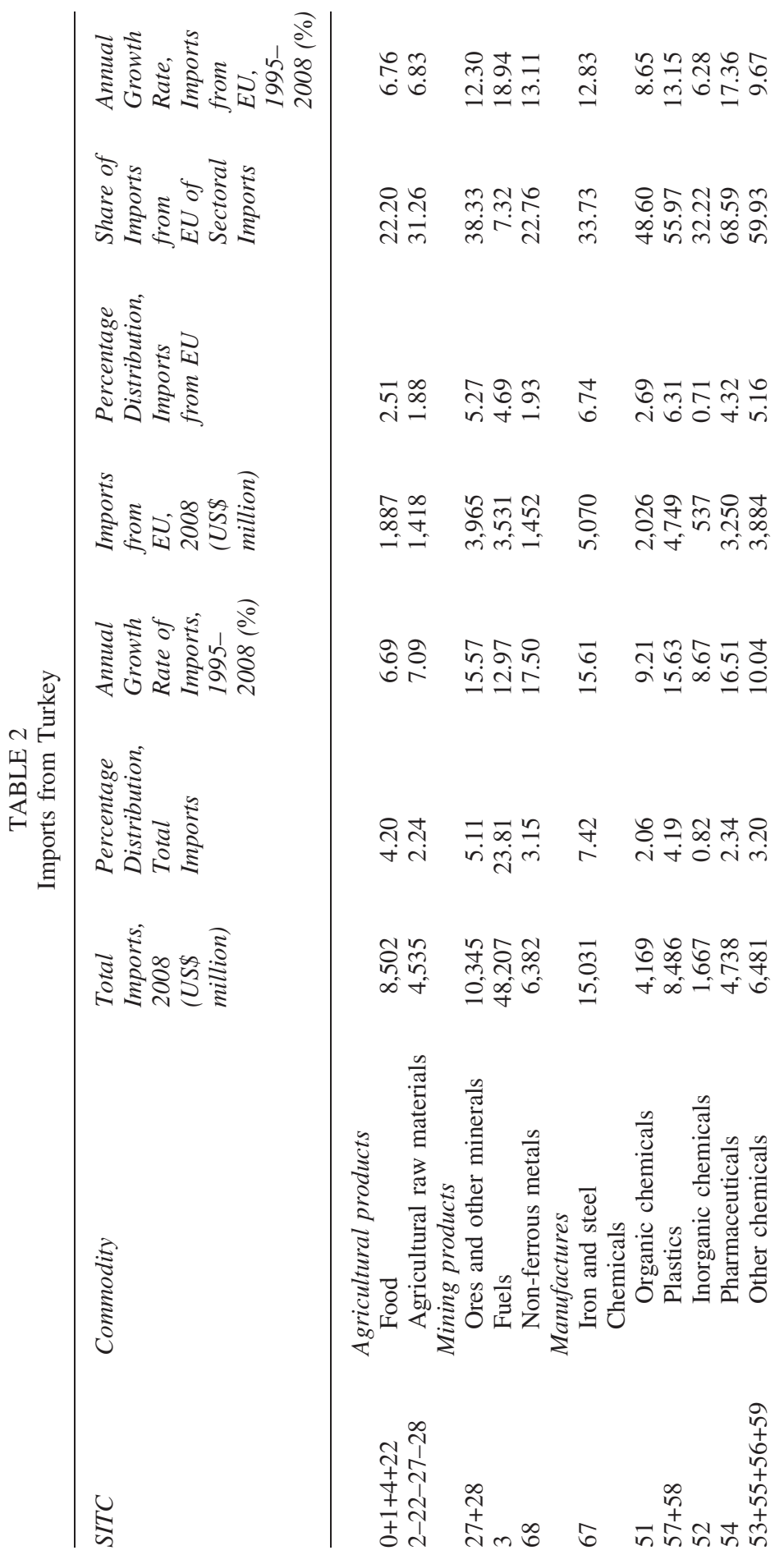


@

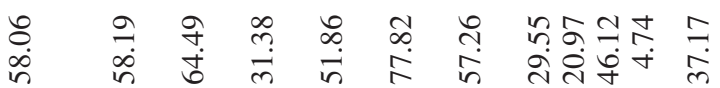

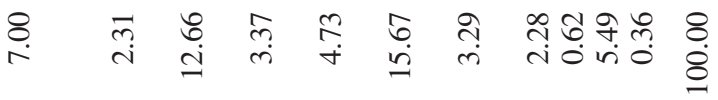

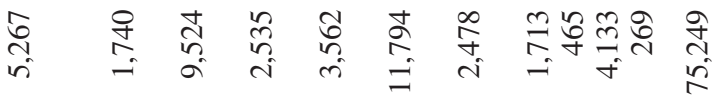

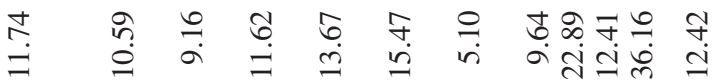

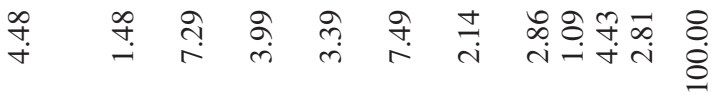

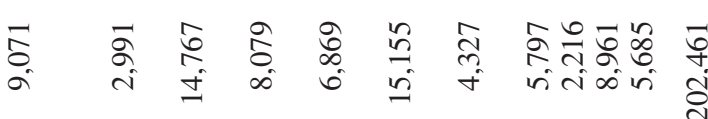
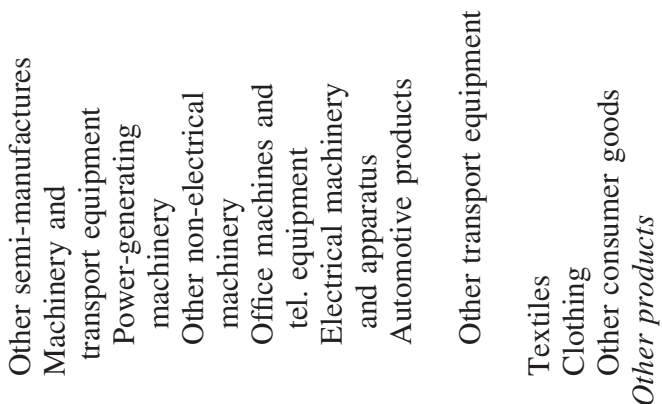

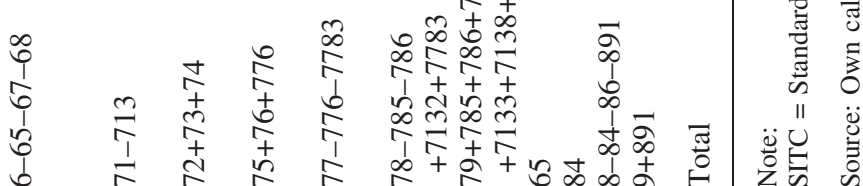


TABLE 3

Sectoral Distribution of Foreign Direct Investment Inflows (US\$ million)

\begin{tabular}{lrrrrr}
\hline Sectors & 2004 & 2005 & 2006 & 2007 & 2008 \\
\hline Agriculture, hunting and forestry & 4 & 5 & 5 & 5 & 26 \\
Fishing & 2 & 2 & 1 & 3 & 19 \\
Mining and quarrying & 73 & 40 & 122 & 336 & 173 \\
Manufacturing & 190 & 785 & 1,866 & 4,210 & 3,828 \\
$\quad$ Manufacture of food products and beverages & 78 & 68 & 608 & 766 & 1,279 \\
Manufacture of textiles & 9 & 180 & 26 & 232 & 190 \\
Manufacture of chemicals and chemical products & 38 & 174 & 601 & 1,109 & 202 \\
Manufacture of machinery and equipment & 6 & 13 & 54 & 48 & 223 \\
Manufacture of electrical optical equipment & 2 & 13 & 53 & 117 & 243 \\
Manufacture of motor vehicles, trailers and semi-trailers & 27 & 106 & 63 & 70 & 67 \\
Other manufacturing & 30 & 231 & 461 & 1,868 & 1,624 \\
Electricity, gas and water supply & 66 & 4 & 112 & 567 & 1,053 \\
Construction & 3 & 80 & 222 & 285 & 720 \\
Wholesale and retail trade & 72 & 68 & 1,166 & 169 & 2,073 \\
Hotels and restaurants & 1 & 42 & 23 & 33 & 27 \\
Transport, storage and communications & 639 & 3,285 & 6,696 & 1,116 & 169 \\
Financial services & 69 & 4,018 & 6,957 & 11,662 & 5,925 \\
Real estate, renting and business activities & 3 & 29 & 99 & 560 & 673 \\
Health and social services & 35 & 74 & 265 & 177 & 150 \\
Other community, social and personal service activities & 33 & 103 & 105 & 13 & 59 \\
Total & 1,190 & 8,535 & 17,639 & 19,136 & 14,895 \\
\hline
\end{tabular}

Source: Undersecretariat of the Treasury.

negotiations with Turkey, and liberalisation measures introduced during the last seven years, FDI inflows have increased considerably. They reached US\$20.2 billion in 2006, US\$22.1 billion in 2007 and US\$18.2 billion in 2008.

Table 3, showing the sectoral distribution of FDI inflows into Turkey over the period 2004-08, reveals that during the last five years the sectors attracting the highest amount of FDI have been services and manufacturing. While the average share of services in total FDI inflows over the period 2006-08 amounted to 79.2 per cent, the average share of manufacturing in total FDI inflow over the same period was 19.4 per cent. In services the 'financial services' and 'transport, storage and communications' received the highest amount of investment with 59.7 and 17.3 per cent, respectively. In manufacturing the highest amount of investment was received by 'manufacture of food products and beverages' and 'manufacture of chemicals and chemical products' with 28.1 and 21.3 per cent, respectively. On the other hand, Table 4, showing the FDI inflows by country of origin over the period 2004-08, reveals that the EU has been the largest investor in Turkey. While the share of the EU in total FDI inflows over the period 2006-08 amounted to 74.6 per cent, the share of the US was 10.9 per cent and the share of Gulf countries 8.2 per cent. In the EU the largest investors have been those from the Netherlands with a share of 31.2 per cent in total FDI inflows 
TABLE 4

Foreign Direct Investment Inflows by Country of Origin (US\$ million)

\begin{tabular}{lrrrrr}
\hline & 2004 & 2005 & 2006 & 2007 & 2008 \\
\hline EU countries & 1,027 & 5,006 & 14,489 & 12,600 & 11,281 \\
Germany & 73 & 391 & 357 & 954 & 1,217 \\
France & 34 & 2,107 & 439 & 368 & 685 \\
Netherlands & 568 & 383 & 5,069 & 5,443 & 1,738 \\
United Kingdom & 126 & 166 & 628 & 702 & 2,294 \\
Italy & 14 & 692 & 189 & 74 & 222 \\
Other EU countries & 212 & 1,267 & 7,807 & 5,059 & 5,125 \\
Other European countries & 6 & 1,646 & 85 & 373 & 291 \\
African countries & - & 3 & 21 & 5 & 82 \\
USA & 36 & 88 & 848 & 4,212 & 863 \\
Canada & 61 & 26 & 121 & 11 & 24 \\
Americas & - & 8 & 33 & 494 & 60 \\
Asia & 60 & 1,756 & 1,927 & 1,405 & 2,292 \\
$\quad$ Near and Middle Eastern countries & 54 & 1,678 & 1,910 & 608 & 2,132 \\
$\quad$ Gulf countries & 43 & 1,675 & 1,783 & 311 & 1,911 \\
$\quad$ Other Near and Middle Eastern countries & 11 & 2 & 3 & 196 & 96 \\
Other Asian countries & 6 & 78 & 17 & 797 & 160 \\
Other countries & - & 2 & 115 & 36 & 2 \\
Total & 1,190 & 8,535 & 17,639 & 19,136 & 14,895 \\
\hline
\end{tabular}

Source: Undersecretariat of the Treasury.

from the EU over the period 2006-08, and United Kingdom with a share of 10.1 per cent.

Finally, we note that Turkey's annual FDI outflows amounted to US\$0.92 billion in 2006, US\$2.11 billion in 2007 and US\$2.59 billion in 2008, averaging US\$1.87 billion over the period 2006-08.

\section{TRADE POLICY}

Over the last 13 years Turkey has been quite successful in amending its domestic legislation to reflect both its EU and WTO commitments.

\section{a. Measures Affecting Imports}

Goods imported into Turkey are subject to various charges: customs taxes and levies (customs tariffs, and the mass housing fund levy); and internal taxes (excise duties, i.e. special consumption tax, value-added tax (VAT), and stamp duty). As of 2009 Turkey's tariff comprises 16,800 lines at the Harmonised Commodity Description and Coding System (HS) 12-digit level.

As a result of the Uruguay Round, 46.3 per cent of tariff lines in Turkey are now bound (all tariff lines for agricultural products and some 36 per cent of 
the lines for non-agricultural products). Final bindings range from zero to 225 per cent on agricultural products, and from zero to 102 per cent on non-agricultural goods. The simple average bound tariff rate amounts to 33.9 per cent.

In Turkey there are two other sets of tariff rates besides the bound tariff rates. These are the applied tariff rates and the statutory tariff rates. Law No. 474 on Customs Tariff Schedule has set the so-called statutory tariff rates. The law enables the government to increase the applied MFN tariff rates for a given year when they are deemed not high enough to provide 'adequate' protection to domestic industries. Under the law, the government can replace applied MFN tariff rates by 150 per cent of the corresponding rates of the statutory tariff with a view to ensuring higher protection to local industries. In the case of products subject to tariff bindings, when the new rate is higher than the corresponding bound tariff rate, then the latter applies. But in cases where the tariff rate is specified as 'exempt', the equivalent applied tariff rate is zero per cent and the government cannot increase the applied tariff rate above zero per cent. Hence, the 'exempt' status in the tariff schedule provides added protection to Turkey's trade liberalisation commitments.

The applied tariff schedule in Turkey is rather complex..$^{5}$ It consists of a large number of lists specifying the tariff lines classified at the HS 12-digit level, for different country groups and countries. List I displays customs duties applied to imports of agricultural products, excluding fish and fishery products. List II shows customs duties to be applied to imports of industrial products and products covered by the ECSC. List III lays down customs duties applied to imports of processed agricultural products, and List IV the customs duties applied to imports of fish and fishery products. List V displays reduced customs duties applied to imports of certain products used as raw materials in the fertiliser, chemical, plastics, textile and electrical machinery industries. Finally, List VI lists the commodities that could be imported by the civil air transportation sector with zero tariff rates. The six lists are accompanied by six annexes. Annexes 1 and 2 show the specific tariff rates applied to imports of processed agricultural products distinguished by the content of milk fat and cornstarch/glucose. While Annex 3 lists the three groups of countries benefiting from the GSP regime, Annexes 4 and 5 list the sensitive and non-sensitive sectors benefiting again from the GSP regime.

Turkey's tariff comprises ad valorem and non-ad valorem rates consisting of specific, mixed, compound and formula duties. Most of the tariffs are ad valorem. Specific taxes (Mass Housing Fund levy) are applied on the imports of certain fish and fishery products specified in List IV as well as on the imports of certain products in List II. On the other hand, the mixed, compound and formula duties apply on processed agricultural commodities specified in List III. In List III the

\footnotetext{
${ }^{5}$ I would like to thank Şinasi Demirbaş and Taşkın Barış Ergün of the Undersecretariat of Foreign Trade for explaining certain aspects of this complex tariff schedule.
} 
duties range between 0 and 368.25 euro/100 $\mathrm{kg}$ depending on the content of milk fat and cornstarch/glucose. ${ }^{6}$ Finally, we note that products listed in List V are in general more specific than those listed in List II. For products listed in both List $\mathrm{V}$ and List II we take the minimum of the two tariff rates.

For the calculation of nominal protection rates we introduce the following notation. Let $t_{c}^{i}$ denote the rate of ad valorem customs duty on commodity $i$; $M_{i}$ c.i.f. value of the import of commodity $i$ measured in Turkish lira; $m_{i}$ quantity of the import of commodity $i$ measured in units the Mass Housing Fund levy is reported; $F U N D_{1}^{i}$ the euro-denominated Mass Housing Fund levy on commodity $i ; F U N D_{2}^{i}$ ad valorem Mass Housing Fund tax rate on commodity $i$; and $E$ exchange rate (Turkish lira per euro). ${ }^{7}$ The base of the customs duty on commodity $i$ is the c.i.f. value of the import of commodity $i$. Therefore, this duty is calculated as $t_{c}^{i} M_{i}$. The Mass Housing Fund levy is usually specific. For these specific tariff rates the ad valorem equivalents of these rates need to be calculated. Given the foreign price of the commodity, $p_{j}^{\text {Euro }}=M_{j} / m_{j} E$, the Turkish lira equivalent of the euro-denominated levy is calculated from the relation $F U N D_{1}^{i} m_{i} E=\left(M_{i}\left(F U N D_{1}^{i} / p_{i}^{E u r o}\right)\right)$. Hence, the ad valorem equivalent is given by $\left(F U N D_{1}^{i} / p_{i}^{E u r o}\right)$. On the other hand, when the Mass Housing Fund tax is specified in ad valorem terms the equivalent tariff revenue is given by $F U N D_{2}^{i} M_{i}$. The sum total of all the above taxes and surcharges is then denoted by $t_{i}=\left(t_{c}^{i}+\left(F U N D_{1}^{i} / p_{i}^{\text {Euro }}\right)+F U N D_{2}^{i}\right)$.

On imported commodities Turkey imposes value-added tax (VAT) as well as special consumption tax (SCT). The base of SCT is the value of imported commodities inclusive of import taxes and surcharges, i.e. $\left(1+t_{i}\right) M_{i}$. On the other hand, the base of VAT is the value of imported commodities inclusive of import taxes, surcharges and the SCT. Letting $v^{2} t_{i}$ be the value-added tax rate on commodity $i, s c t_{i}$ the special consumption tax rate on commodity $i$, the special consumption tax rate on imported commodity $i$ is calculated as

$$
S C T_{i}=s c t_{i}\left(1+t_{c}^{i}+\left(F U N D_{1}^{i} / p_{i}^{\text {Euro }}\right)+F U N D_{2}^{i}\right) .
$$

Similarly, the VAT rate on imported commodity $i$ is determined as

$$
V A T_{i}=\operatorname{vat}_{i}\left[\left(1+t_{c}^{i}+\left(F U N D_{1}^{i} / p_{i}^{\text {Euro }}\right)+F U N D_{2}^{i}\right)+S C T_{i}\right] .
$$

Noting that domestically-produced commodities are subject to VAT and SCT at the rates $v a t_{i}$ and $s c t_{i}$, respectively, the nominal protection rate (NPR) on

\footnotetext{
${ }^{6}$ Here it should be emphasised that in line with the CUD, processed agricultural products imported into Turkey from the EU are subject to customs duties comprising an industrial and agricultural component. While all industrial components enjoy duty-free treatment, few agricultural components are subject to preferential treatment. MFN customs duties still apply to most agricultural components, where these components are calculated by multiplying the quantity of primary agricultural product used in processing, according to an agreed set of ratios, by the specific rate charge.

Note that the Mass Housing Fund levy is denominated in euros.
} 
imported commodity $i\left(N P R_{i}\right)$, measuring the protection provided to commodity $i$ relative to domestic production of commodity $i$, equals

$$
N P R_{i}=t_{i}+S C T_{i}+V A T_{i}-v a t_{i}\left(1+s c t_{i}\right)-s c t_{i} .
$$

When we consider the average protection rate in a particular sector $j$ with $k$ commodities in the sector the simple average protection rate is calculated as $\sum_{i=1}^{k} N P R_{i}^{j} / k$, where $N P R_{i}^{j}$ denotes the average protection rate on commodity $i$ of sector $j$.

It was stated above that Annexes 1 and 2 of the tariff schedule show among others the specific tariff rates applied to imports of processed agricultural products distinguished by the content of milk fat and cornstarch/glucose, and that the specific tariff rate for a specific 12-digit HS commodity indicated as T1 and T2 in List III may vary between 0 and $368.25 \mathrm{euro} / 100 \mathrm{~kg}$ depending on the content of milk fat and cornstarch/glucose. Thus, one cannot obtain the ad valorem equivalent of the specific tariff rate for those 12-digit HS commodities unless one has information on the milk fat and cornstarch/glucose contents of those commodities imported. To obtain the ad valorem equivalent of the specific tariff rates for each 12-digit HS commodity in List III, for which the specific tariffs are stated as T1 and T2, we first determine the total Housing Fund taxes collected on each 12-digit HS commodity under consideration by country groups (EU + EFTA, and other countries). Next we divide the Housing Fund tax collected on each 12-digit HS commodity under consideration by country groups by the value of import of the corresponding 12-digit HS commodity again by country group, and obtain the ad valorem tariff equivalent for each 12-digit HS commodity in List III, for which the specific tariffs are stated as T1 and T2. ${ }^{8}$

Table 5 shows the NPRs prevailing in 2009, where all non-ad valorem tariffs have been converted to ad valorem equivalents and incorporated into NPRs. In the table, average tariffs for two groups, of countries are listed. These are the EU, and countries for which the MFN tariffs apply. In the table the average NPRs are shown for 19 aggregated HS commodity groups such as 'chemical products', 'textile and textile articles' and 'transport equipment'. The table reveals that in trade with the EU, the overall simple average NPR is 9.12 per cent and the overall simple average MFN protection rate is 13.86 per cent.

In trade with the EU, 17 out of the total of 19 sectors have zero NPRs. The highest protection rates apply in the cases of 'agricultural commodities', and 'chemical products'. In those cases the NPRs are 52.22 per cent and 0.08 per cent, respectively. On the other hand, in the case of trade with countries for

\footnotetext{
${ }^{8}$ I am grateful to Rasim Kutlu of the Undersecretariat for Customs for providing the essential data required for the estimation of the ad valorem equivalent tariff rates for commodities for which the specific tariffs are stated as T1 and T2 in List III.
} 


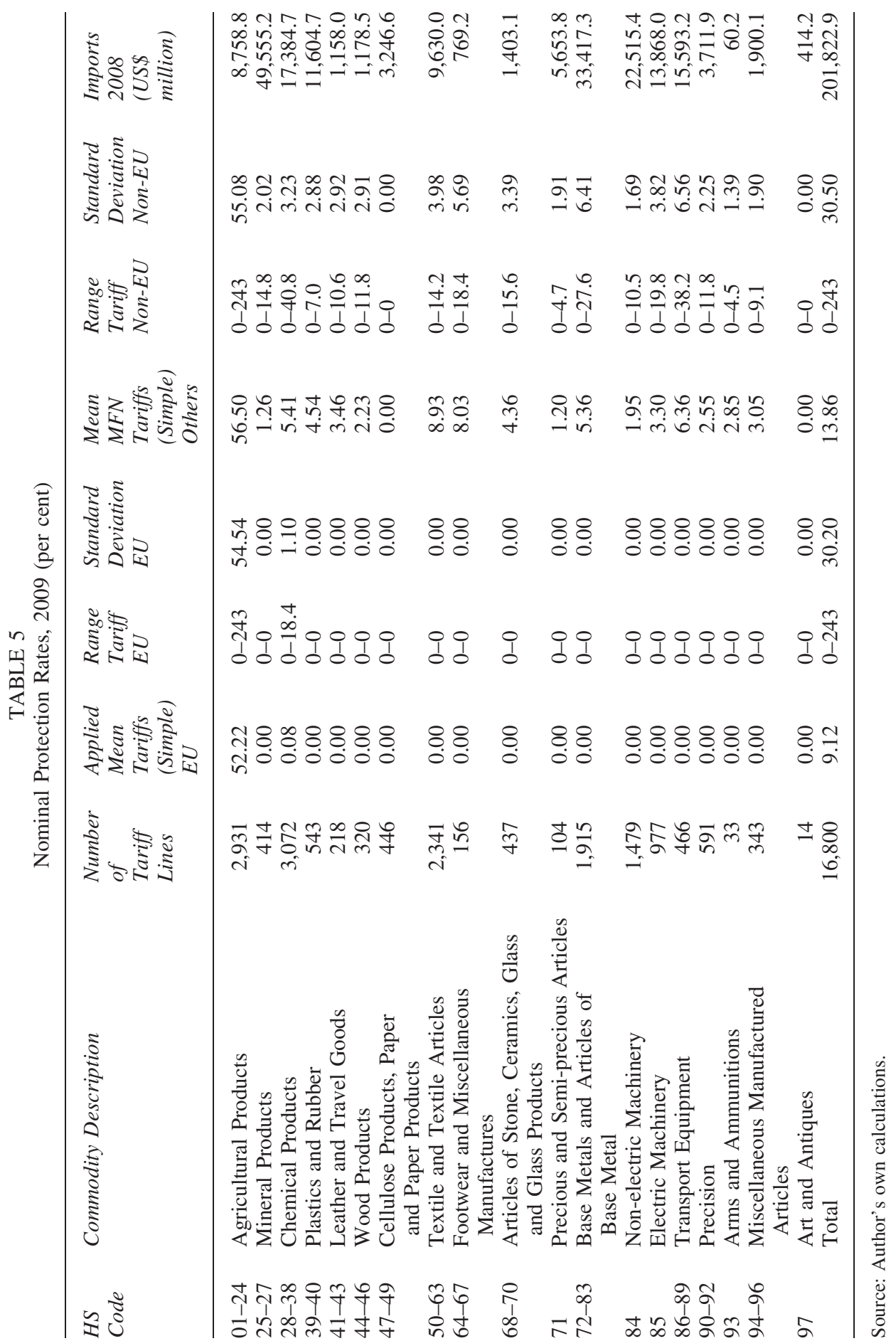


which the MFN tariffs apply, the NPR on 'agricultural products' is 56.5 per cent, 'textiles and textile articles' 8.93 per cent, and 'footwear and miscellaneous manufactures' 8.03 per cent. The figures show that in Turkey the agricultural sector is heavily protected.

Table 6 shows the NPRs for the agricultural commodities in more detail. The table reveals that in trade with the EU the simple average NPR is 50.7 per cent and in trade with countries for which MFN tariffs apply, 54.85 per cent. In the case of trade with the EU the highest average protection rates apply in the cases of 'meat and edible offal', 'milk and dairy products; eggs; honey' and 'products made from meat, fish and crustacea'. In those cases the NPRs are 147.65 per cent, 104.01 per cent and on 102.63 per cent, respectively. On the other hand, in the case of trade with countries for which the MFN tariffs apply the highest average NPRs are imposed on 'meat and edible offal', 'products made from meat, fish and crustacea', and 'milk and dairy products; eggs; honey'. These protection rates are not much different from the protection rates that apply on imports from the EU.

Comparison of the protection rates reported in Tables 5 and 6 with those given in the Trade Policy Review: Turkey 2007 reveals that Turkey's protection rates are higher than those reported in World Trade Organization (2008) for some of the commodity groups. Although the figures in World Trade Organization (2008) refer to the year 2007 and our data to the year 2009, the difference in the result is due mainly to the way the protection rates in the two studies have been estimated. It is interesting to note that while the overall MFN simple average tariff rate in World Trade Organization (2008) is 11.6 per cent, it is 13.86 per cent in our case. Furthermore, when the WTO definition of agricultural products is used, the overall MFN simple average protection rate in agriculture is calculated as 47.6 per cent in World Trade Organization (2008), whereas it is 54.85 per cent in our case. ${ }^{9}$ Divergence of the NPRs calculated through the two different studies is more pronounced in sectors where the tariff rates inclusive of all other taxes and surcharges, value-added tax rates and special consumption tax rates are relatively high, as in the cases of "vehicles other than railway or tramway rolling stock, and parts and accessories thereof' (HS 87).

In Turkey, import prohibitions apply to 10 broad product categories such as narcotics, arms and ammunitions, and ozone-depleting substances for reasons such as environment, public security, health and public morals. Regarding licensing, we note that import licences are required for several categories of products, including some motor vehicles, transmission apparatus, chemicals, fertilisers, endangered species of wild fauna and flora, solvent and petroleum

\footnotetext{
9 WTO definition of agriculture: HS Chapters 01-24 less fish and fishery products (HS 0301-0307, 0509, 051191, 1504, 1603-1605 and 230120) plus some selected products (HS 290543, 290544, 290545, 3301, 3501-3505, 380910, 382311-382319, 382360, 382370, 382460, 4101-4103, 4301, 5001-5003, 5101-5103, 5201-5203, 5301 and 5302). But in our calculations we use the following definition of agriculture: HS Chapters 01-24, 4101-4103, 5101-5103 and 5201-5203.
} 


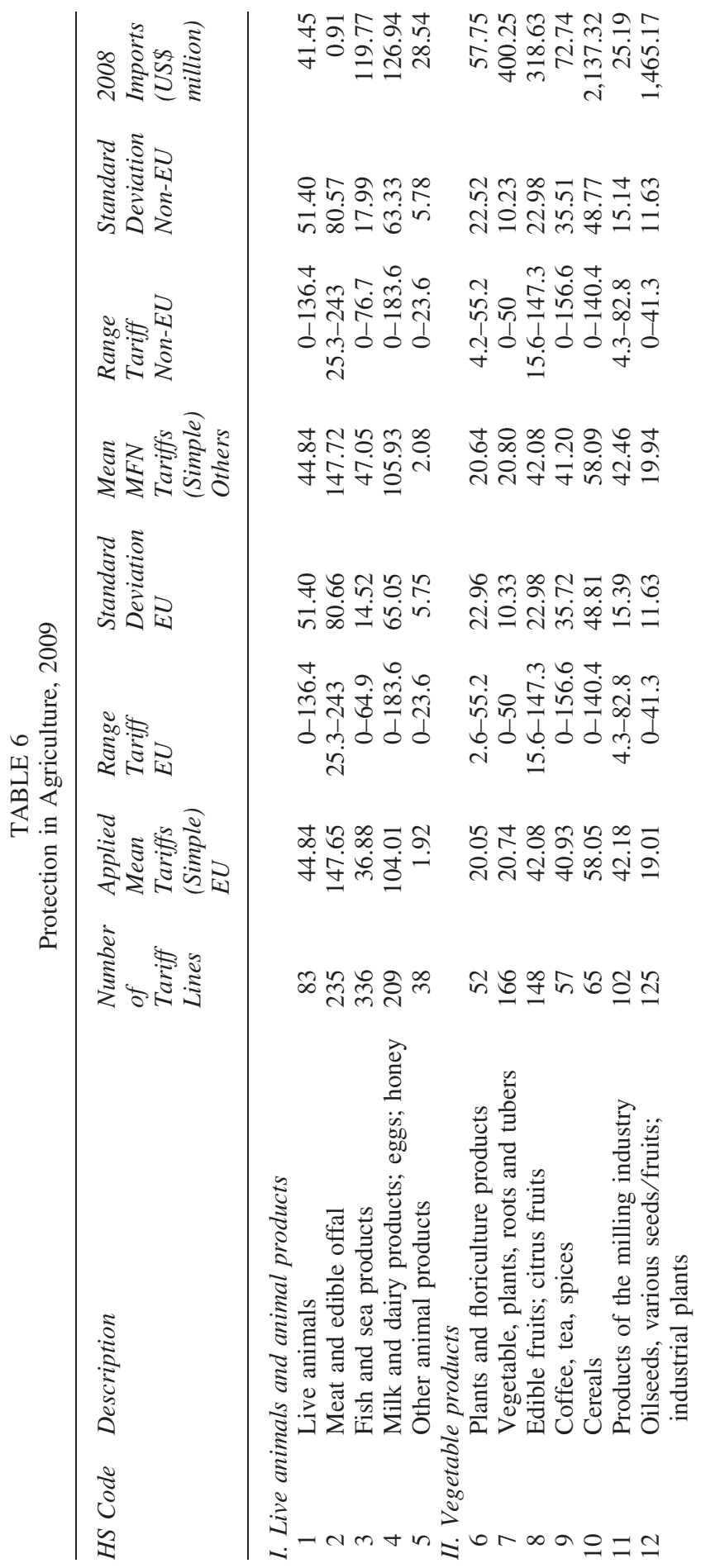




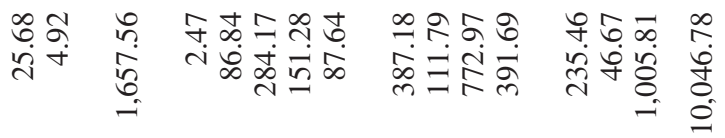

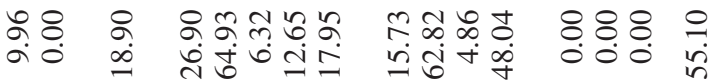

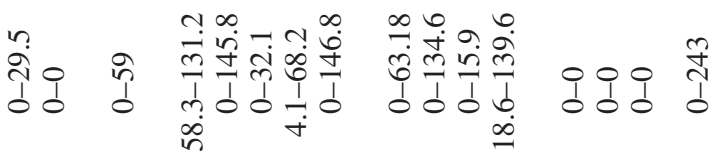

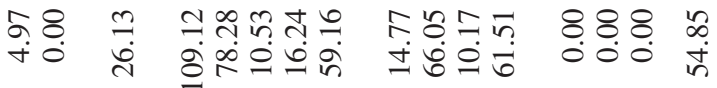

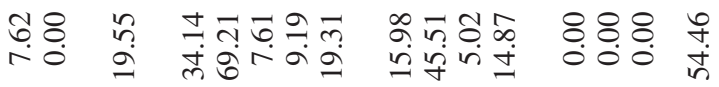

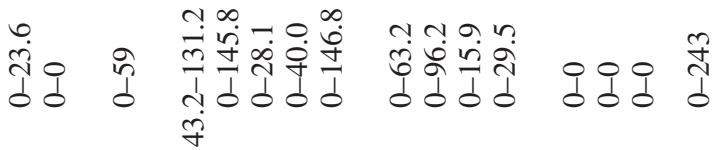

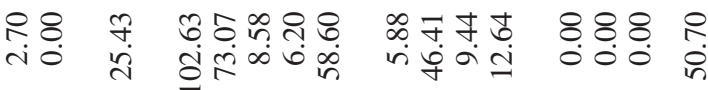

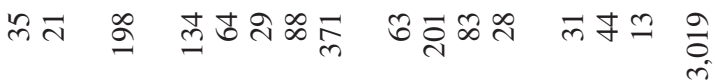

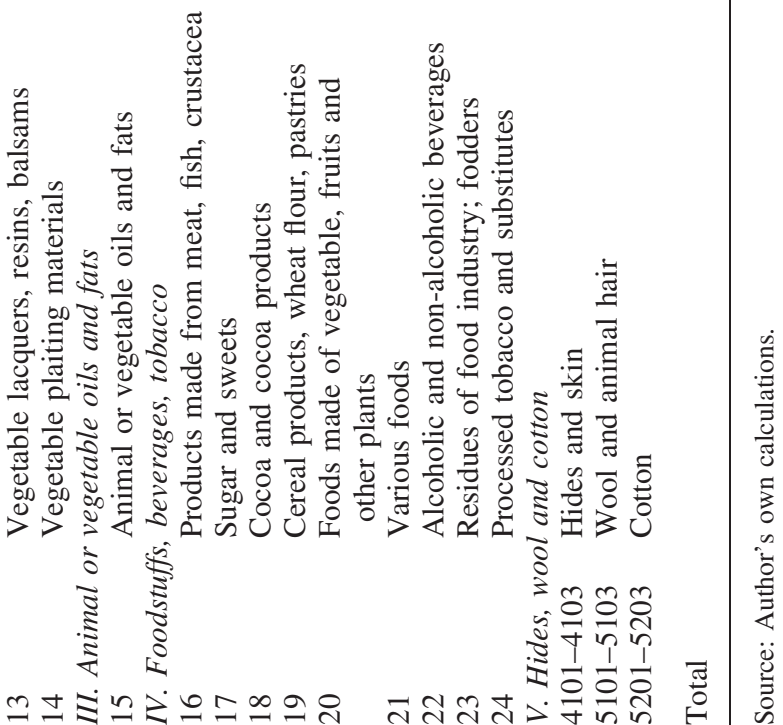


products, and certain sugar substitutes. Importers of these items must obtain permission from the relevant authorities. In addition, the importation of pharmaceuticals, drugs, some medical products, cosmetics, detergents, foodstuffs and packaging materials, fishery products, and agricultural, animal and veterinary products are subject to health and sanitary controls. Imports of agricultural products and foodstuffs require a 'control certificate' issued by the Ministry of Agriculture and Rural Affairs (MARA); and imports of pharmaceutical products, drugs, certain consumable medical products, cosmetics and detergents require a control certificate issued by the Ministry of Health. ${ }^{10}$ Finally, we note that measuring and weighing instruments to be released for free circulation in Turkey are subject to control by the Directorate General of Measures and Standards of the Ministry of Industry and Trade; materials comprising cinematographic and musical works are inspected and examined by the Directorate of Copyright and Cinema with the aim of combating piracy. On the other hand, tariff preferences on agricultural products, granted under Turkey's trade agreements, are generally subject to quotas. Tariff quotas are applied on imports of various agricultural and processed agricultural products from the EU, Israel, Macedonia, Croatia, Bosnia-Herzegovina, Morocco, Syria, Tunisia, Egypt and Albania. In addition, Turkey is applying import quotas on certain textile and clothing products as a requirement for harmonising its import policy with that of the EC. Licensing is used again whenever quotas are imposed.

Regarding contingent protectionism we note that as of the end of 2008, Turkey had 107 anti-dumping duties in force. Most of the anti-dumping duties were imposed on imports from China (42 duties), Indonesia (10 duties), Chinese Taipei (9 duties), Thailand (8 duties) and India (7 duties), and measures have affected mostly textiles and clothing. The majority are specific duties, and some ad valorem duties as high as 100 per cent. Turkey is an important user of anti-dumping measures. As of 31 December 2008 it had 32 anti-dumping investigations in progress, and most of these investigations concerned imports from China. On the other hand, Turkey did not make extensive use of countervailing measures and safeguard actions. It has reported only one countervailing measure against imports from India, and it has not taken any safeguard actions under GATT Article XIX.

\section{b. Measures Affecting Exports}

In Turkey the exportation of certain commodities is subject to registration, and the exportation of some other commodities is prohibited because of

\footnotetext{
${ }^{10}$ Since 1996 MARA has not issued 'control certificates' for imports from countries considered to be risks for diseases. The decision was made on sanitary grounds, and was based on the World Organisation for Animal Health risk classification for live animals (dairy and beef cattle, sheep, goats and poultry) and meat (beef, sheep, goats and poultry).
} 
environmental, health or religious reasons. All other commodities can be exported freely. Exporters are required to register with the Exporters Union and their local chamber of commerce. According to the regulations of the export regime, export prohibitions have been imposed on 'antiques and archaeological works', 'Indian hemp', 'tobacco seedlings and tobacco plants', 'Angora goats', 'game and wild animals', 'walnut, mulberry, cherry, pear, plum, badger, ash, elm, and lime in logs, in timber, in plank and in sketch', 'natural flower bulbs', 'wood and wood charcoal', 'plants of olive, fig, hazelnut, pistachio, and grapevine', 'sahlep', 'liquidamber orientalis', 'pterocarya carpinifolia', and 'dates "Phoenix the ophrasti crenter"'. On the other hand, an export licence is required for 26 categories of products. Exporters of these items must obtain permission from the relevant authorities. The 26 categories include (as of 2009) commodity groups such as 'military weapons and ammunition', 'opium and poppy seeds', 'addictive and psychotropic substances', 'seeds', 'feeds covered by Feed Law', 'pharmaceuticals for veterinary purposes', 'technology and equipment used for nuclear purposes', 'goods covered by Missile Technology Controlling Regime' and 'sugar'. Finally, we note that Turkey applies export taxes at the rate of US\$0.04 per $\mathrm{kg}$ on shelled hazelnuts, US\$0.08 per $\mathrm{kg}$ on unshelled hazelnuts, and US\$0.5 per $\mathrm{kg}$ on raw skins (HS 41.01, 41.02 and 41.03, excluding processed raw skins).

Regarding export incentives we note that as a result of the customs union between the EU and Turkey, as well as Turkey's commitments vis-à-vis the WTO, Turkey has progressively revamped the incentives provided to exporters. Currently, export subsidies are provided through the following programmes: 'cash subsidies', 'Investment Encouragement Program', 'Inward-Processing' scheme, state aid programmes under Ministerial Council Resolution on 'State Aids Related to Exports of 1994', 'export credit scheme of the Turk Eximbank' and 'free zones'.

Cash subsidies are extended to a number of agricultural products and processed agricultural goods including cut flowers, frozen vegetables, frozen fruit and olive oil. Table 7 shows the subsidies extended to these commodities. From the table it follows that subsidies are quite substantial for various commodities, but that the applied subsidy rates cannot exceed specified maximum rates. These rates are set between 5 and 20 per cent of the value of exports, and between 14 and 100 per cent of the quantities exported.

Duty concessions are granted under the 'Investment Encouragement Program' (IEP) which merged the previous 'General Investment Encouragement Program' and the 'Aids Granted to Small and Medium Enterprises' (SMEs) Investments'. The purpose of IEP is to encourage and orient investments, in order to reduce regional imbalances within the country, and to create new employment opportunities, while using technologies with greater value-added. To qualify for the IEP, potential investors must apply for an investment 


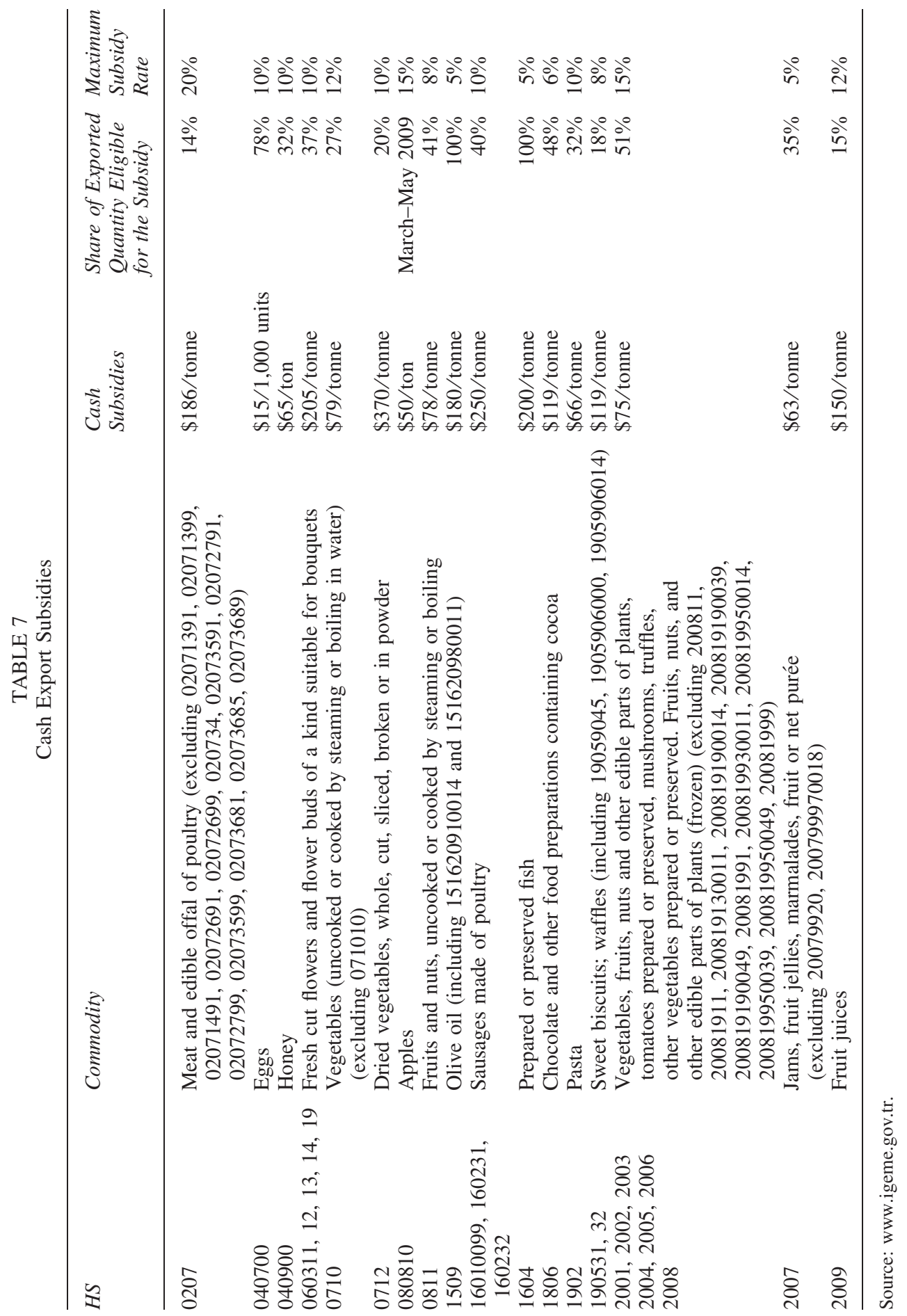


encouragement certificate to be issued by the Undersecretariat of the Treasury. In principle, all investment projects are eligible. If granted a certificate, the project can benefit from incentives which cover (i) exemption from customs duties and fund levies on imported machinery and equipment that are part of the investment project and appear on the machinery and equipment list approved by the Undersecretariat of Treasury; (ii) VAT exemption for imported and locally purchased machinery and equipment; (iii) 'interest support', by certain percentage points of the interest rate, on credits obtained on commercial terms by investors to finance their investment projects; and (iv) electricity cost support for tourism investments and establishments. Furthermore, foreign exchange earning activities are exempt from stamp duties and related charges. SME investments can also benefit from the encouragement measures offered under the IEP.

In addition to the IEP scheme, the Inward-Processing (IP) scheme also benefits exporters. Goods imported under the IP scheme are intended for re-export from the customs territory of Turkey in the form of 'compensating products'. ${ }^{11}$ The system works through suspension of duties and VAT until the exportation of the products, or reimbursement based on a drawback method. The suspension system is used whenever there is a 'substantiated' intention to re-export the goods in the form of compensating products. Under the drawback system, used mainly for inward processing, repayment of the import duty and VAT can be reclaimed when the compensating products are exported.

Under Ministerial Council Resolution on 'State Aids Related to Exports of 1994', Turkey provides nine different state aid programmes, carried out by various public bodies/institutions and organisations. The programmes are 'state aid for organising domestic fairs with international participation', 'state aid for environmental protection activities', 'state aid for research and development projects', 'state aid for encouraging employment in sectoral foreign trade companies', 'state aid for participation in international fairs and exhibitions', 'state aid for operating stores abroad', 'state aid for promoting Turkish trade marks and improving the image of Turkish goods', 'state aid for market research projects' and 'state aid for vocational training'. ${ }^{12}$

${ }^{11}$ Compensating products are all goods obtained from processing operations.

12 'State aid for organising domestic fairs with international participation' provides up to 50 per cent of promotional activities not exceeding US $\$ 25,000 ; 50$ per cent of transportation expenses of representatives of foreign companies not exceeding US\$15,000; and 50 per cent of expenses regarding activities during the fair not exceeding US $\$ 5,000$. 'State aid for environmental protection activities' covers up to 50 per cent of the relevant certification expenses. 'State aid for research and development projects' provides 50 per cent and up to a maximum of 60 per cent grant for R\&D activities for three years. In addition, capital support is provided in the form of support for two years up to US\$1 million, and a soft loan up to US\$100,000 for one year to be paid back in US\$ with interest. 'State aid for encouraging employment in sectoral foreign trade companies' provides 75 per cent of the pre-tax salary for one manager and two staff with professional experience, for one 
Preferential export credits are extended by the Export Credit Bank of Turkey (Turk Eximbank), which operates a large number of export credit, guarantee and insurance schemes. Short-term financial assistance through Turk Eximbank is made available to exporters at the pre-shipment and post-shipment stages with a term up to 360 days for credits in Turkish lira and 540 days for credits in foreign currency. Credits are allocated through the Turkish commercial banks or directly by the Turk Eximbank. Turk Eximbank's medium- and longterm financial support programmes have been developed mainly for the export of capital goods and turnkey investment projects to be undertaken by Turkish and Turkey-based contractors. The majority of these programmes involve extending financing facilities to buyers outside of Turkey for the purchase of Turkish goods and/or services. For many medium- and long-term operations, a sovereign guarantee in favour of Turk Eximbank has been a prerequisite for extension of the facility. Moreover, export receivables are discounted in order to promote sales on deferred payment conditions and to increase export trade volumes. The Turk Eximbank also offers Turkish exporters, investors and overseas contractors a variety of insurance policies against commercial and political risks. Commercial risk-based losses are indemnified by Turk Eximbank from its own resources, while political risks are, in principle, backed by the government. Since 2000, short-term political risks have also been ceded to the reinsurance panel within certain country limits.

Since the passage of the law on free zones in 1985, 20 zones have been established in Turkey. The zones are open to a wide range of activities. Offshore banking, insurance business and customs brokers are not allowed, but all industrial, other commercial and service operations deemed appropriate by the Supreme Planning Board may be conducted. There is no limitation on foreign capital participation in investment within the free zones, and 100 per cent repat-

year. 'State aid for participation in international fairs and exhibitions' includes, in the case of national participation, 50 per cent of participation fees not exceeding US\$10,000-15,000; and 5075 per cent of the rental cost of empty stands not exceeding US\$10,000-15,000. In addition, 75 per cent of promotional expenses will be covered not exceeding US\$80,000-120,000. 'State aid for operating stores abroad' covers 50-60 per cent of the advertisement, rent, office inventory and decoration expenditures of companies operating a store abroad depending on the type of firm involved. In those cases promotional expenses up to certain limits will also be covered by the aid programme. 'State aid for promoting Turkish trade marks and improving the image of Turkish goods' provides 50 per cent of consultancy fees, rental fees, advertisement, certification expenses and fees for the registration of trade marks. The upper limit of support depends on the type of organisation involved. 'State aid for market research projects' provides support for buying market research projects, reports and statistics; financial assistance for companies participating in trade missions abroad, and for becoming members of e-trade websites in order to market their products abroad. The amount of support provided depends on the type of activity. Finally, 'state aid for vocational training' covers support for improving quality, productivity, management techniques, design, international marketing and foreign trade operations. The support amount to 90 per cent of training costs for programmes up to six months, 75 per cent of consultancy services costs up to one year, and one-year tuition costs of selected designers. 
riation of capital is allowed without prior permission, tax, duty or fee. In addition, financial incentives are available to free zone companies, and these include exemption from payment of customs duties and fees, and value-added taxes; no restrictions on profit transfer and for foreign exchange transactions. Under Law No. 5084 of 2004 on the 'Encouragement of Investments and Employment' only free zone users that operate under a production licence are exempted from the income or corporate taxes until the end of the taxation period of the year in which Turkey becomes a full member of the EC. ${ }^{13}$ For other free zone users that obtained an operating licence before February 2004, the income or corporate tax exemption will apply for the validity period of the operating licence, and income tax on wages will not be paid until 2009. On the other hand, free zone users that had obtained an operating licence other than for production after February 2004, do not enjoy income or corporate tax exemption. In contrast to most other free zones, sales to the Turkish domestic market are allowed. But goods and revenues transported from the zones into Turkey are subject to all relevant import regulations.

\section{c. Foreign Direct Investment Framework}

Until very recently annual FDI inflows into Turkey amounted to less than $\$ 1$ billion. The result was mainly due to economic and political uncertainties surrounding the country and the enormous institutional, legal and judicial obstacles faced by foreign investors. Furthermore, the inadequate functioning of regulatory bodies that foresaw competition in service and infrastructure industries such as telecommunications, energy and finance made entry and exit into these markets extremely difficult. ${ }^{14}$ The situation improved considerably with the introduction of the 2001 programme of economic stabilisation, implementation of its privatisation programme, the EU's 2004 decision to begin membership negotiations with Turkey, and liberalisation measures introduced over recent years.

The Decree on Improving the Investment Environment in Turkey was enacted at the end of 2001 as a part of the national strategy to increase domestic and foreign investments by improving the business environment, increasing the overall level of income and productivity, and raising the level of competitiveness. The Decree also established the Coordination Council for the Improvement of the Investment Environment and technical subcommittees to identify and remove the remaining regulatory and administrative barriers to pri-

\footnotetext{
${ }^{13}$ Under the prevailing regulations for operations and practices in the zones the validity period of an operating licence is a maximum of 10 years for tenant users, and 20 years for users who wish to build their own offices in the zone; if the operating licence is for production, the terms are 15 and 30 years for tenant users and investors, respectively.

14 See Izmen and Yilmaz (2009).
} 
vate investment. Since then, the authorities have implemented several legislative measures to further improve the business and investment climate, including the adoption of the Foreign Direct Investment Law No. 4875 in 2003, and the establishment of the Turkish Investment Support and Promotion Agency in June 2006. ${ }^{15}$

The aim of the 2003 Foreign Direct Investment Law is to: (i) encourage FDIs in the country; (ii) protect foreign investors' rights; (iii) bring investors and investments in line with international standards; (iv) establish a notification-based rather than approval-based system for FDIs; and (v) increase the volume of FDI through established policies. The law provides a definition of foreign investors and foreign direct investments, and explains the important principles of FDIs, such as freedom to invest, national treatment, expropriation and nationalisation, transfers, access to real estate, dispute settlement, valuation of non-cash capital, employment of expatriates, and liaison offices. The new law has removed the screening and pre-approval procedures for FDI projects, re-designed the company registration process on an equal footing for domestic and foreign firms, facilitated the hiring of foreign employees, included FDI firms in the definition of 'domestic tenderer' in public procurement, and authorised foreign persons and companies to acquire real estate in Turkey. All companies established under the rules of the Turkish Commercial Code are regarded as Turkish companies. Therefore, equal treatment is applicable to all such companies, both in rights and responsibilities as stated in the Constitution and other laws. According to the law a company can be 100 per cent foreign owned in almost all sectors of the economy. However, a number of sectors are still subject to FDI restrictions. Establishments in broadcasting, aviation, maritime transportation, port services, fishing, accounting, auditing and bookkeeping services, financial sector, petroleum, mining, electricity, education and private employment offices require special permission, according to appropriate laws. Finally, regarding acquisition of land we note that until 2003, foreigners were not allowed to acquire property in Turkey. With the new FDI Act foreigners can acquire land in accordance with the mutuality principle. But, acquisition of land of between 2.5 and 30 hectares is subject to permission from the Council of Ministers. ${ }^{16}$

The Investment Promotion and Support Agency provides information to interested investors, as well as incentives such as the provision and development of investment sites for specific investment projects. The agency aims to function in the future as a one-stop shop where all bureaucratic procedures can be handled within a very short period of time. Finally, note that Turkey has

\footnotetext{
${ }^{15}$ See World Trade Organization (2008).

16 As a result US $\$ 2.9$ billion on average annually have been invested in real estate during the period 2006-08.
} 
been a member of the International Centre for Settlement of Investment Disputes and the Multilateral Investment Guarantee Agency since 1987. Furthermore, since 1991 Turkey has been a member of the Convention on the Recognition and Enforcement of Foreign Arbitral Awards, and of the European Convention on International Commercial Arbitration. In addition, Turkey has developed since 1962 an impressive network of bilateral agreements with 80 countries, the main purpose of which has been to promote investment flows between parties, ensure a more stable investment environment, provide economic and legal assurance to foreign investors, and to establish a favourable environment for economic cooperation. Turkey has also signed double taxation prevention treaties with 68 countries, which enables tax paid in one of two countries to be offset against tax payable in the other, thus preventing double taxation, and Social Security Agreements with 22 countries, which make it easier for expatriates to move between countries.

Although the investment climate in Turkey has improved considerably over the last seven years, the change is still not reflected in the various international competitiveness studies such as the IMD (International Institute for Management Development) World Competitiveness Report. While Turkey was ranked as the 48th country in the IMD World Competitiveness Report for 2001, it was ranked again as the 48th country in 2007 and 2008, and it is lagging far behind many of its competitors: the Czech Republic ranks 28th, the Slovak Republic 30th, Spain 33rd, Portugal 37th, Hungary 38th, Greece 42nd and Poland 44th. This poor record is also confirmed by the Doing Business Survey of the World Bank which ranks Turkey as the 57th country among 178 countries. On the other hand, according to a 2006 study conducted by the OECD's overall FDI regulatory restrictiveness index, Turkey's most restrictive sectors are air and maritime transport, followed by electricity, and its most liberal sectors are in manufacturing, together with some service sub-sectors, such as telecommunications, insurance services and certain business services. ${ }^{17}$

As emphasised above, FDI inflows into Turkey during the last five years have increased considerably. They reached US $\$ 20.2$ billion in 2006, US $\$ 22.1$ billion in 2007 and US $\$ 18.2$ billion in 2008. But an important shortcoming of these inflows has been its composition. Almost all of the FDI inflows over the last four years have been composed of mergers and acquisitions, and directed towards service sectors and real estate. From a longer-term growth perspective Turkey needs to attract greenfield investments. ${ }^{18}$ In order for Turkey to participate in international producers' networks the current investment environment should further be improved by the implementation of long-delayed judicial and legal reforms.

${ }^{17}$ See OECD (2006).

18 See Izmen and Yilmaz (2009). 


\section{TECHNICAL BARRIERS TO TRADE}

The above considerations reveal that Turkish protection rates are very low except for agricultural commodities. Hence, one could state that tariffs for Turkey are largely a non-issue in the non-agricultural sector. Currently there is free movement of industrial products between the EU and Turkey - with the exception of contingent protectionism measures and technical legislation. Regarding contingent protectionism we note that both the EU and Turkey have been active users of contingent protection measures, but more so the EU. The formation of the customs union has not provided protection from EC anti-dumping, and the EU has continued to protect its sensitive sectors through contingent protection measures. But the development of free trade between the EU and Turkey has been hindered mainly because of non-elimination of technical barriers to trade (TBT). Although 13 years have passed since the formation of the EU-Turkey customs union, TBTs between Turkey and the EU could still not be eliminated, although considerable effort has been made by Turkey. ${ }^{19}$

Different approaches are available for countries to raise standards and to address TBTs. Countries can unilaterally upgrade standards by adopting international standards. But some of the returns to adopting the international standards - in terms of greater market access - only materialise if the country's trading partners also accept products produced to that standard in the country under consideration. A second approach requires cooperation between a specified number of countries to upgrade standards by agreeing that products satisfying particular standards will be accepted in each other's markets. Turkey has adopted the second approach for elimination of TBTs when it formed the customs union with the EU in 1995. This section, discussing the policies pursued by Turkey towards the elimination of TBTs, consists of three sub-sections. While the first sub-section is on standards, conformity assessment and trade in general terms, the second sub-section discusses the EU approach to elimination of TBTs and the third sub-section the Turkish approach to elimination of TBTs.

\section{a. Standards, Conformity Assessment and Trade}

Product standards, technical regulations and conformity assessment systems are essential ingredients of functioning modern economies. While a 'standard' is defined as a set of characteristics or quantities that describes features of a product, process, service or material, 'technical regulation' is a mandatory requirement imposed by public authorities. Technical regulations and standards,

19 This section draws heavily on the joint work with Saadettin Doğan. I am grateful to Frederic Misrahi for his detailed and constructive comments on an earlier draft of the paper. 
despite many similarities, have different impacts. If a product does not fulfil the requirements of a technical regulation, it will not be allowed to be put on sale. In the case of standards, non-complying products will be allowed on the market but, then, the volume of sales may be affected if consumers prefer products that meet the standards. While the distinction between product standards and technical regulations is useful for policy purposes, in the following we use the term 'standards' to refer to both mandatory requirements and voluntary specifications. Finally, 'conformity assessment' is the comprehensive term for measures taken by manufacturers, their customers, regulatory authorities and independent third parties to assess conformity to standards.

Product and process standards serve the functions of fostering commercial communication, diffusing technology, raising productive efficiency, enhancing market competition, ensuring physical and functional compatibility, and enhancing public welfare. ${ }^{20}$ Standards reduce the transaction costs for buyer and seller by conveying information regarding the inherent characteristics and quality of products. They facilitate market transactions. Under standardisation, products become closer substitutes, increasing the elasticity of substitution in demand between versions of similar products. As a result, standards enhance competition by allowing products that conform to a given standard to compete directly with each other. Moreover, standardisation in manufacturing enables efficiency-increasing measures such as repetitive production, reduced inventories and flexibility in substituting components on the assembly line, bringing about significant economies of scale. The economies of scale, in turn, benefit the producer through cost reductions, which can then be passed on to the consumer as lower prices. In addition, compatibility standards are important in industries that are organised into networks, such as telecommunications. The more widespread a given network standard becomes, the greater the incentive becomes for additional users to adopt that standard. Moreover, standards diffuse technical information embodied in products and processes, when a technological advance by a designer, researcher or developer at one firm is incorporated into a standard used by others. Thereby, standards help to raise productivity and industrial competitiveness. They also contribute to the provision of public goods. While emission standards can contribute to cleaner air, health standards can raise the average heath status in the economy. Since a standard can be used any number of times without depleting its utility, it is also a public good, raising questions about the provision of standards by the private sector only.

Standards are developed in three main ways. First, a standard may arise from a formal coordinated process, in which key participants in a market, such as producers, designers, consumers, corporate and government purchasing offi-

${ }^{20}$ See National Academy of Sciences (1995), Stephenson (1997) and Maskus and Wilson (2001). 
cials, and regulatory authorities seek consensus on the best technical specifications to meet customer, industry and public needs. The resulting standards are then published for voluntary use throughout industry. Second, a standard may arise from uncoordinated processes in the competitive marketplace. When a particular set of products or process specifications gains market share, such that it acquires influence, the set of specifications is considered a de facto standard. Third, a standard may be set by the government for which compliance is required, either by regulation or in order to sell products or services to government agencies. In this context, a procurement standard may specify requirements that must be met by suppliers to the government, and a regulatory standard may set safety, environmental or related criteria.

Conformity assessment enhances the value of standards by increasing the confidence of buyers, users and regulators that products actually conform to claimed standards. Over time, the definition of conformity assessment has gained different meanings, as developments occurred in conformity assessment procedures. Currently, it requires the close interrelation between 'parties assessing conformity to standards', accreditation, calibration and metrology.

Testing is the determination of the characteristics of a product, process or service, according to certain procedures, methodologies or requirements; the aim of testing may be to check whether a product fulfils specifications such as safety requirements or characteristics relevant for commerce and trade. The extent of the controls that a product must undergo varies according to the risk attached to the use of the product. Requirements may range from a declaration by the manufacturer stating that certain standards have been applied to extensive testing and certification. In a large number of cases, tests are carried out by the manufacturer, based on internal testing and quality assurance mechanisms. In such cases, the purchaser takes the manufacturer's word that the product conforms. However, in more risky situations, the manufacturer's declaration of conformity may not be sufficient. The use of independent laboratories may be required by the customer as a condition of sale or mandated by a regulatory agency. Alternatively, through testing and other means, the purchaser may insist on formal verification by an unbiased third party that a product conforms to specific standards. In this case, certification is the procedure by which a third party gives written assurance that a product, process or service conforms to specified requirements. In sectors with high demands for safety and reliability, certifiers may require a relatively intensive certification process involving multiple tests, one or more factor inspections, and testing large numbers of product samples.

Conformity assessment systems consist not only of testers and of certifiers evaluating products, processes and services, but they also incorporate accreditation and recognition. While accreditation refers to the procedure by which an authoritative body gives formal recognition that a body responsible for conformity assessment is competent to carry out specific tasks, recognition is the 
evaluation of the competence of the accreditors. Many large manufacturers require their suppliers' testing laboratories to be accredited as a condition for accepting suppliers' products. As emphasised by the National Academy of Sciences (1995), accreditation of a laboratory's or certifier's competence in a particular field typically involves a review of technical procedures, staff qualifications, product sample handling, test equipment calibration and maintenance, quality control, independence, and financial stability. To maintain accredited status, periodic reassessment, with follow-up testing and site visits, may also be required.

One of the most significant factors in any conformity assessment system is the reliability of measurements. This reliability can only be achieved by calibrating the measuring devices. Almost all countries have national metrology centres, the main objectives of which are to build and maintain national standards for all measurements carried out within the country and to calibrate the measurement standards and devices of lower-level laboratories. National centres with accredited laboratories form the national measurement system and coordinate their activities. Thus, metrology delivers the basis for the comparability of test results, e.g. by defining the units of measurement and by providing traceability and associated certainty of the measurement results. In many countries, a National Metrology Institute exists, which maintains primary standards of measurement used to provide traceability to customers' instruments through calibration. $^{21}$

The benefits of standards and conformity assessment systems apply also across borders. However, standards and conformity assessment systems can also impose additional costs to exporters and act as barriers to trade. TBTs are said to exist as long as countries impose different product standards as conditions for the entry, sale and use of commodities; as long as the different countries have different legal regulations on health, safety and environmental protection; and as long as different parties have dissimilar procedures for testing and certification to ensure conformity to existing regulations or standards. ${ }^{22}$

Stephenson (1997) points out that many disputes over technical barriers arise from mandatory government requirements for standards, due to differing national interpretations of the reasonableness of the regulations in question, such as the scientific interpretation of tolerable health and safety risks for consumers of various products. Non-tariff barriers also arise through increased product costs created by the often redundant testing and certification for different national markets; increased transportation costs, if the product is deemed not to comply with the importer's regulatory requirements; and time and

${ }^{21}$ See Howarth and Redgrave (2003).

22 See Sykes (1995) on technical barriers to trade. 
administrative delays caused by costly and lengthy inspection visits by the importing country's authorities.

Technical barriers have two aspects: (i) the content of the norms (regulations and standards); and (ii) the testing procedures needed to demonstrate that a product complies with a norm. The TBTs thus come in two basic forms, content-of-norm TBTs and testing TBTs. In either case, the costs of the product design adaptations, the reorganisation of production systems, and the multiple testing and certification needed by exporters can be high. These costs are, on the one hand, up-front and one-time and, on the other, ongoing. While the up-front costs are associated with learning about the regulations and bringing the product into conformity with the regulations, the ongoing costs are related to periodic testing. TBTs are said to distort trade when they raise the costs of foreign firms relative to those of domestic firms. As emphasised by Baldwin (2001), liberalisation requires closing the gap between the costs of the foreign and domestic firms. The two main dimensions to such a step are liberalisation of the content of norms and liberalisation of conformity assessment. Liberalisation of the content of norms involves making product norms more cosmopolitan and, thus, narrowing the cost advantage of domestic firms. Liberalisation of conformity assessment involves lowering the excess costs that foreign firms face in demonstrating the compliance of their goods to accepted norms.

\section{b. The EU Approach to Elimination of Technical Barriers to Trade}

The European Commission (1998) divides traded products into regulated and non-regulated commodities. Regulated products are those whose commercialisation is governed by the regulations of Member States, and non-regulated products are those for which no regulations have an impact on commercialisation. Regulated products are further divided into commodities under the harmonised sphere and under the non-harmonised sphere. Products under the harmonised sphere are covered by European rules for the harmonisation of regulations and mandatory specifications, and commodities under the non-harmonised sphere are governed by national rules. ${ }^{23}$

\section{(i) Mutual recognition principle}

Mutual recognition refers to the principles enshrined in the Treaty of Rome, interpreted by the European Court of Justice, as set out in the 1979 Cassis de

\footnotetext{
${ }^{23}$ The general principle of the free movement of goods implies that products must be traded freely from one part of the EU to another. This principle is enshrined in the EC Treaty, in particular Articles 28 to 30, 95(4) to 95(9), 296 to 298, as interpreted in the case law of the European Court of Justice as well as in Commission Directive 70/50/EEC and interpretative communications.
} 
Dijon judgment. In this ruling, the court stated that Germany could prohibit imports of a French beverage (Cassis de Dijon) only if it could invoke mandatory requirements such as public health, protection of the environment, and fairness of commercial transactions. In other words, the court introduced a broad definition of Article 28 (ex 30) of the Treaty of Rome, which prohibits quantitative restrictions on imports between Member States and 'all measures having equivalent results'. Because of this ruling, the European Commission stated that a product lawfully produced and marketed in one Member State should be admitted to other Member States for sale, except in cases of mandatory requirements. Thus, the basic EU approach under the mutual recognition principle (MRP), considered as the first line of defence against technical barriers in the regulated non-harmonised sphere, has been to promote the idea that products manufactured and tested in accordance with a partner country's regulations could offer levels of protection equivalent to those provided by corresponding domestic rules and procedures. Mutual recognition, in other words, reflects the existence of ex ante trust between the trading partners.

The Directive 98/34/EC, covering all industrial and agricultural commodities which fall outside the 'harmonised' area, aims to eliminate or reduce the barriers to the free movement of goods which can arise from the adoption of different national technical regulations, by encouraging transparency of national initiatives vis-à-vis the European Commission, European standardisation bodies and other Member States. According to the Directive, Member States are obliged to notify to the Commission, in draft, proposed technical regulations and to observe a three-month standstill period before the regulation is made or brought into force. ${ }^{24}$ The Commission circulates the notified drafts to all Member States. In order to allow the Commission and other Member States to react, the Member States must refrain from adopting any draft technical regulations for three months from the date of receipt by the Commission. The standstill period is extended to four months for drafts in the form of a voluntary agreement and for six months for all others where the Commission delivers a detailed opinion indicating that the draft may impede the free movement of goods. This notification procedure is to provide an opportunity for the Commis-

\footnotetext{
${ }^{24}$ Technical regulations refer to 'technical specification', a specification contained in a document which lays down the characteristics required of a product such as levels of quality, performance, safety or dimensions, including the requirements applicable to the product as regards the name under which the product is sold, terminology, symbols, testing and test methods, packaging, marking or labelling and conformity assessment procedures. The term 'technical specification' also covers production methods and processes. Other requirements include a requirement, other than a technical specification, imposed on a product for the purpose of protecting, in particular, consumers or the environment, and which affects its life cycle after it has been placed on the market, such as conditions of use, recycling, reuse or disposal, where such conditions can significantly influence the composition or nature of the product or its marketing.
} 
sion and other Member States to comment if they consider that the proposed regulation has the potential to create a technical barrier to trade.

According to the European Commission (2007) national technical rules adopted by various Member States lead to substantial obstacles to the free movement of goods within the EU, resulting in extra administrative controls and tests, and the system of market surveillance needed considerable improvement, as there was no consistency of approach. As a result, the European Parliament and the Council adopted the Resolution (EC) No. 764/2008, which defines the rights and obligations of national authorities and enterprises wishing to sell in a Member State products lawfully marketed in another Member State, when the competent authorities intend to take restrictive measures about the product in accordance with national technical rules. The Regulation concentrates on the burden of proof by setting out the procedural requirements for denying mutual recognition.

(ii) Harmonisation of national regulations and standards

EU legislation on harmonising technical specifications has followed two distinct approaches: the old approach and the new approach.

The old approach was based on the idea that the EU would become a unified economic area functioning like a single national economy. It dealt with the content-of-standards issue via negotiated harmonisation. The regulations were implemented by the directives of the European Council, and the designated bodies in EU nations performed the conformity assessments. Technical regulations were harmonised using the old approach for foodstuffs, motor vehicles, chemicals, pharmaceuticals, cosmetics, textiles, footwear labelling, crystal glass, legal metrology and pre-packaging. Under this approach, separate directives for different products detailed EU specifications that applied to the related products and their testing requirements. Under the old approach, European standards institutions such as CEN (Comité Européen de Normalisation), CENELEC (Comité Européen de Normalisation Electrotechnique) and ETSI (European Telecommunications Standards Institute) were not mandated to draw up supplementary technical specifications. ${ }^{25}$ The old approach involved exten-

${ }^{25}$ CEN (European Committee for Standardisation), based in Brussels, has a membership consisting of the national standards-writing organisations of European countries and the members of the EU and EFTA. CEN develops voluntary European standards in all product sectors excluding electrical standards covered by CENELEC. The sectors are air and space, information and communications technologies, chemistry, materials, construction, measurement, consumer products, mechanical engineering, energy and utilities, nanotechnology, environment, security and defence, food, services, health and safety, transport and packaging, healthcare, heating, cooling and ventilation. These standards are also national standards in each of its member countries. With funding from the European Commission, CEN also writes standards to meet the 'essential requirements' for product safety mandated in EU product directives. CENELEC (European Committee for Electrotechnical Standardisation), based in Brussels, has European national electrotechnical committees as members. 
sive product-by-product or even component-by-component legislation, and was carried out by detailed directives. Achieving this type of harmonisation was slow, as emphasised by the World Bank (2005), for two reasons. First, the process of harmonisation became highly technical, with attention given to very detailed product categories. Consultations were often drawn out. Second, the adoption of directives required unanimity in the Council, which meant that they were slow to be adopted. ${ }^{26}$ Over time, the need was recognised by economic units to reduce the intervention of the public authorities prior to a product being placed on the market and to change the decision-making procedure to allow for the adoption of harmonisation directives by a qualified majority. Therefore, the 'new approach' was adopted, and it applied to products with 'similar characteristics' that were subject to a widespread divergence of technical regulations in EU countries.

Under the new approach, only 'essential requirements' are indicated. This approach gives manufacturers greater freedom on how they satisfy those requirements by dispensing with the 'old' type of exhaustively detailed directives. Directives under the new approach provide for more flexibility, by using the support of the established standardisation bodies - CEN, CENELEC, ETSI and the national standard bodies. This standardisation work is easier to update and involves greater participation from industry.

Under the new approach, the European Council issues a directive that outlines 'essential requirements'. So far, 26 directives have been adopted based on this approach, and 21 of these directives require the affixing of the CE (Conformité Européene) marking, explained in more detail below. This new approach to product legislation covers the areas of non-automatic weighing instruments and measuring instruments, low voltage equipment, electromagnetic compatibility, toys, machinery, lifts, noise emissions by outdoors equipment, emissions of pollutants from non-road mobile machinery engines, personal protective equipment, equipment and protective systems intended for use in explosive atmospheres, medical devices, gas appliances, pressure vessels, cableway installations, construction products, recreational craft, eco-design requirements for energy-using

CENELEC develops European standards for electrotechnology. CENELEC also develops standards that meet EU product directives, with funding from the European Commission. On the other hand, ETSI produces globally applicable standards for Information \& Communications Technologies including fixed, mobile, radio, broadcast, internet and several other areas. Currently, ETSI is recognised as an official European Standards Organisation by the European Commission, enabling valuable access to European markets.

26 With the entry into force of the 1985 Single European Act, a qualified majority voting system was adopted in the decision-making process for internal market-related legislation. As a result when new old-approach directives or Acts revising existing old-approach directives are adopted, qualified majority voting is used. Furthermore, the decision-making procedure for internal market-related legislation currently is typically co-decision between the European Parliament and the Council of Ministers. 
products, and radio and telecommunications terminal equipment. Once a new approach directive has been issued, Member States must make their national laws and regulations conform to it. The European Commission is empowered to determine whether the national measures are equivalent to the 'essential requirements'. The Council refers the task of formulating detailed standards that meet the essential requirements to CEN, CENELEC and the ETSI.

\section{(iii) Conformity assessment}

To ensure that products meet the requirements laid down in the new approach directives, special conformity assessment procedures have been established. They describe the controls to which products must be subjected before they are considered compatible with the essential requirements and thus placed on the internal market. The extent of the controls a product must undergo varies, according to the risk attached to the use of the product. Requirements may range from a declaration by the manufacturer stating that certain standards have been applied, to extensive testing and certification by third parties, called notified bodies in the EU. ${ }^{27}$

In 1993, Council Decision 93/465/EEC was adopted in connection with the new approach directives. It provides an overview of all conformity assessment procedures available under the directives, divided up into modules and grouped by category of risk. By standardising the conformity assessment procedures the Decision ensures coherence and transparency in the application of the directives. It divides conformity assessment into eight different modules, which cover the design and production phases. The modules specify how conformity assessment procedures used in new approach directives are organised. In setting the range of possible choices open to the manufacturer, the directives (i) take into consideration, in particular, such issues as the appropriateness of the modules to the type of products, the nature of the risks involved, the economic infrastructures of the given sector, the types and importance of production, etc., and (ii) attempt to leave as wide a choice to the manufacturer as is consistent with ensuring compliance with the requirements. The specifications of the eight modules are as follows:

Under Module A on 'internal control of production' covering internal design and production control, the manufacturer prepares technical documentation and declares conformity with the directive. ${ }^{28}$ The module does not require the intervention by a notified body. Under Module B on 'EC type-examination' covering the design phase, the manufacturer prepares technical documentation and

\footnotetext{
27 Notified bodies are explained in more detail in the following.

${ }^{28}$ Technical documentation and the EC declaration of conformity are explained in more detail in the following.
} 
the notified body ascertains conformity. The module is followed by one of the Modules C, D, E and F providing for the assessment in the production phase.

- Module $\mathrm{C}$ on 'conformity to type' provides for conformity with the type as described in the EC type-examination certificate issued according to Module B. The module does not require the intervention of a notified body. ${ }^{29}$

- Module D on 'production quality assurance' derives from the quality assurance standard EN ISO 9002, with the intervention of a notified body responsible for approving and controlling the quality system for production, final product inspection and testing set up by the manufacturer.

- Module E on 'product quality assurance' derives from quality assurance standard EN ISO 9003, with the intervention of a notified body responsible for approving and controlling the quality system for final product inspection and testing set up by the manufacturer.

- Under Module F on 'product verification' a notified body controls conformity to the type as described in the EC type-examination certificate issued according to Module B, and issues a certificate of conformity.

Module G on 'unit verification' covers the design and production phases. Each individual product is examined by a notified body, which issues a certificate of conformity. Finally, Module H on 'full quality assurance' covers the design and production phases. It derives from quality assurance standard EN ISO 9001, with the intervention of a notified body responsible for approving and controlling the quality system for design, manufacture, final product inspection and testing set up by the manufacturer.

The new approach directives oblige the manufacturer to draw up a technical file (technical documentation), which provides information on the design and manufacturing phases of the product. The contents of the technical documentation are laid down with the requirements of the directive to be assessed. ${ }^{30}$ The

\footnotetext{
29 Type examination is the comparison of the design specification of a product against the requirements of a standard specification, informed by physical examination of a sample and the performance of tests as may be necessary according to the particular standard.

30 The following might be required to be included in technical documentation: (i) a general description of the product; (ii) overall drawing of a product, design and manufacture drawings and diagrams of components, sub-assemblies, control circuits, etc., together with descriptions and explanations needed to understand those drawings and diagrams; (iii) risk analysis and a description of methods adopted to eliminate hazards presented by the product; (iv) the essential requirements of the applicable directives; (v) a list of the standards used, in full or in part, and a description of the solutions employed to meet the essential requirements of applicable directives; (vi) other technical specifications, which were used; (vii) results of design calculations and of checks carried out, etc.; (viii) test reports and/or certificates, which may be available, either by the manufacturer or a third party (depending on the requirements of the directives); and (ix) a copy of the instructions (for use, for maintenance, other instructions).
} 
details included in the documentation depend on the nature of the product and on what is considered as necessary, from the technical point of view, for demonstrating the conformity of the product to the essential requirements of the relevant directive. The manufacturer must also draw up an EC declaration of conformity as part of the conformity assessment procedure provided for in the new approach directives. The EC declaration of conformity should contain all relevant information to identify the directives according to which it is issued, as well as the manufacturer, the notified body if applicable, the product, and where appropriate a reference to harmonised standards or other normative documents. ${ }^{31}$ The technical file and the EC declaration of conformity must be kept for at least 10 years from the last date of manufacture of the product, unless the directive expressly provides for any other duration, and this is the responsibility of the manufacturer.

For products regulated by the new approach directives, the mandatory $\mathrm{CE}$ marking confirms conformity with the essential requirements of the directives and is required for a product to be placed on the internal market. The CE marking indicates not only that the product has been manufactured in conformity with the requirements of the directive, but also that the manufacturer has followed all the prescribed procedures for conformity assessment. It ensures free access to the entire EU.

The above considerations reveal that conformity assessment varies in levels of difficulty and complexity, depending on the level of risk associated with the product. For example, Module A permits the manufacturer to assume total responsibility for conformity assessment. If the product is manufactured to harmonised standards, and if the risk is not unusually high, the manufacturer may rely on internal manufacturing checks. The manufacturer compiles the technical file, issues a declaration of conformity to the appropriate directives, and, if appropriate, standards, applies the CE marking, and places the product on the market. On the other hand, as the risk of injury associated with a product increases, the level of complexity of the conformity assessment process and the associated cost increases with it. Certain high-risk products may not be self-certified, but must be subjected to an EC type-examination. This

\footnotetext{
31 As a minimum the following information should be provided by the EC declaration of conformity: (i) the name and address of the manufacturer; (ii) the identification of the product (name, type or model number, and any relevant supplementary information, such as lot, batch or serial number, sources and numbers of items); (iii) all relevant provisions complied with; (iv) the referenced standards or other normative documents (such as national technical standards and specifications) in a precise, complete and clearly defined way; (v) all supplementary information that may be required (for example, grade, category), if applicable; (vi) the date of issue of the declaration; (vii) signature and title or an equivalent marking of authorised person; and (viii) the statement that the declaration is issued under the sole responsibility of the manufacturer and, if applicable, the authorised representative.
} 
examination involves the inspection of a representative example by a notified body. ${ }^{32}$

Notified bodies are independent testing houses, laboratories or product certifiers authorised by the EU Member States to perform the conformity assessment tasks specified in directives. A notified body is designated by a Member State and must have the necessary qualifications to meet the testing and/or certification requirements set forth in a directive. A notified body not only needs to be technically competent and capable of carrying out the specified conformity assessment procedures, but it must also demonstrate independence, impartiality and integrity. Accreditation, according to the EN ISO 45000 series of standards, is a support to the technical part of notification and, although it is not a requirement, it remains an important and privileged instrument for evaluating the competence, impartiality and integrity of the bodies to be notified.

In order to build and maintain confidence between the Member States concerning the assessment of notified bodies, it is essential to apply the same assessment criteria. It is also important that the bodies performing the assessment of notified bodies have the capability to do so and can demonstrate an equivalent competence and operate according to the same criteria, and that such requirements are laid down in EN ISO 45003 and EN ISO 45010. The European Commission (1997) emphasises that accreditation systems at a national level should be set up under the aegis of the public authorities. It maintains that accreditation systems must be commercially independent and that accreditation services be offered in a competent, transparent, neutral, independent and nondiscriminatory manner. Furthermore, the national accreditation bodies should become members of a European organisation covering all countries of the EU and EFTA, to ensure proper coordination as well as the development of appropriate mutual recognition mechanisms. Such an organisation was formed in 2000 as the European Co-operation for Accreditation (EA), which resulted from the merger of the European Accreditation of Certification (EAC) and the European Co-operation for Accreditation of Laboratories (EAL).

Finally, note that conformity assessment procedures differ for classical approach and new approach directives. The above text describes the procedures for new approach directives. The general procedures, however, also apply to a large extent for bodies working with conformity assessments under old approach directives. There are, however, some differences. Since the old approach directives contain specified technical requirements, 'product standards' as defined formally above are used to a very limited extent. Conformity

\footnotetext{
32 Delaney and van de Zande (2000) note that modules for active implantable medical devices could call for a type-examination of the product, plus a production quality assurance system that conforms to the ISO 9002 (EN 29002) standard. Another choice for a medical device manufacturer would be a complete quality assurance programme that would conform to ISO 9001 (or EN 29001). In those cases where the risk is high, the modules will call for the involvement of the notified body.
} 
assessment bodies that deal with new approach directives officially are named 'Notified Bodies', while bodies working with old approach directives officially are named 'Technical Services'. The new approach directives are based on essentially private pre-market certification. However, notified bodies may also be public. Thus, in the new approach pre-market certification is competitive as opposed to exclusively public authority-based certification in the old approach.

\section{(iv) Market surveillance}

The final stage of implementation of the new approach system consists of market surveillance procedures that develop a common approach to enforcement. The main objective of market surveillance is to place only safe products on the market. Market surveillance consists of the control that the relevant authorities in the Member States are required to carry out to ensure that the criteria for CE marking have been satisfied - after the products have been placed on the market.

For areas under the new approach directives, the system in use is in-market control. Under this system, the responsibility for placing a product on the market is left to the producer, as long as the product is certified to satisfy the minimum requirements set under the directives. Market surveillance is the responsibility of public authorities. As emphasised by the European Commission (2000), each Member State can decide upon the market surveillance infrastructure. There is no limitation on the allocation of responsibilities between authorities on a functional or geographical basis, as long as surveillance is efficient and covers the whole territory. Market surveillance authorities must perform their operations in an impartial and non-discriminatory way. They must have the power, competence and resources to visit commercial, industrial and storage facilities regularly; to visit regularly, if appropriate, workplaces and other premises where products are put into service to organise random checks and spot checks; to take samples of products and subject them to examination and testing; and to require all necessary information. Thus, market surveillance is carried out in the form of random inspections to ensure that the technical documentation, as required by the directive, is available, but it may also include examination of the documentation or the product itself. The control is intended to prevent misuse of the $\mathrm{CE}$ marking, to protect consumers and to secure a level playing field for producers. New approach directives provide for two different tools that enable surveillance authorities to receive information on the product: the EC declaration of conformity and the technical documentation. These must be made available by the manufacturer, the authorised representative established within the community, or under certain circumstances by the importer or person responsible for placing the product on the market. Monitoring of products placed on the market may be divided between several authorities at the national level, for example, functionally or geographically. 
Where the same products are subject to control by more than one authority, coordination between services within a Member State is necessary.

The coordination task between different market surveillance bodies in a Member State can be accomplished by a market surveillance authority. Regarding personnel resources, this authority needs to have, or have access to, a sufficient number of suitably qualified and experienced staff, with the necessary professional integrity. The testing facilities should comply with the relevant criteria of the EN ISO 45001 standard. The authority should be independent and carry out its operations in an impartial and non-discriminatory way. ${ }^{33}$ For market surveillance to be efficient, resources should be concentrated where risks are likely to be higher or non-compliance more frequent, or where a particular interest can be identified.

Through the market surveillance system described above, measures are taken in the EU to ensure that products meet the requirements of the applicable directives, that action is taken to bring non-compliant products into compliance, and that sanctions are applied when necessary. Member States are free to choose the type of sanction to use. The only requirement is that the penalties be effective, proportionate and dissuasive. But the above text describes the surveillance procedures for the new approach directives. For other commodities surveillance could be discussed in terms of the general safety directive (2001/95/EC), rapid exchange of information (RAPEX), and the principle of product liability as developed by Directive 85/374/EEC.

The General Product Safety Directive 2001/95/EC is aimed at ensuring that consumer products placed on the market are safe. The Directive obliges the Member States to take the measures necessary to enforce the safety requirements for which it provides and to notify any such measures taken. To that effect, the Directive sets up a system for rapid exchange of information (RAPEX) concerning products posing a serious risk to consumers. ${ }^{34}$ The

\footnotetext{
33 See European Commission (2000).

34 RAPEX is the EU rapid alert system for dangerous consumer products with the exception of food, pharmaceutical and medical devices, which are covered by other mechanisms. It facilitates the rapid exchange of information between Member States and the Commission on measures taken to prevent or restrict the marketing or use of products posing a serious risk to the health and safety of consumers. RAPEX works as follows. When a product is found to be dangerous, the competent national authority takes appropriate action to eliminate the risk. It can withdraw the product from the market, recall it from consumers or issue warnings. The National Contact Point then informs the European Commission about the product, the risks it poses to consumers and the measures taken by the authority to prevent risks and accidents. The European Commission disseminates the information that it receives to the National Contact Points of all other EU countries. It publishes weekly overviews of dangerous products and the measures taken to eliminate the risks on the internet. The National Contact Points in each EU country ensure that the authorities responsible check whether the newly notified dangerous product is present on the market. If so, the authorities take measures to eliminate the risk, either by requiring that the product be withdrawn from the market, by recalling it from consumers or by issuing warnings.
} 
General Product Safety Directive also imposes obligations on producers and distributors. Producers and distributors are to inform the national authorities if they know or ought to know, on the basis of information in their possession and as professionals, that a product they have placed on the market is dangerous. On the other hand, Directive 85/374/EEC establishes the principle of objective liability or liability without fault of the producer in cases of damage caused by a defective product. According to the Directive, people injured by defective products may have the right to sue for damages, the injured person can take action against producers as well as importers, and liability applies to all goods used at a place of work and food.

\section{(v) Epilogue}

According to the European Commission (2007) almost all the promises on the internal market for goods that were made in the 1985 White Paper on the completion of the Internal Market were kept. Almost all technical barriers to intraEU trade in goods were eliminated through the application of Articles 28 to 30 EC Treaty and through secondary EC legislation. After determining that the Internal Market for goods was still not complete as of 2007, a new legislative framework was adopted in 2008. The new package of measures has the objective of removing the remaining obstacles to free circulation of products. The legal texts include Regulation (EC) No. 765/2008 setting out the requirements for accreditation and market surveillance relating to the marketing of products, and Regulation (EC) No. 768/2008 on a common framework for the marketing of products. The objective of the package is to facilitate the functioning of the internal market for goods and to strengthen and modernise the conditions for placing a wide range of industrial products on the EU market. The package builds upon existing systems to introduce clear Community policies which will strengthen the application and enforcement of internal market legislation.

\section{c. Turkish Approach to Elimination of Technical Barriers to Trade}

According to Decision 1/95 of the EC-Turkey Association Council of 1995 establishing the Customs Union, Turkey must harmonise its technical legislation with that of the EU. ${ }^{35}$ Decision 2/97 of the Association Council of 1997 listed the areas in which Turkey must align its legislation. This work should have been finalised before the end of 2000 , but, unfortunately, due to the lack of suitable legal infrastructure, it was not completed during the specified per-

\footnotetext{
35 Within the framework of Articles 5-7 of the Association Council Decision (ACD) No. 1/95, the signatories shall eliminate not only classical trade-restricting measures such as tariffs and quotas, but also the barriers to trade arising from different regulatory practices on goods in both Turkey and the EU. On the other hand, within the framework of Articles 8-11 of the ACD No. 1/95, Turkey shall progressively adopt the relevant acquis communautaire on the removal of TBTs and all other related technical regulations.
} 
iod. According to Annex II of Decision 2/97, Turkey was supposed to incorporate into its internal legal order 300 instruments that correspond to various EEC or EC regulations and directives. Currently, Turkey has incorporated into its legal order only 236 of these instruments.

Turkey has adopted all 21 new approach directives that require affixing the CE conformity marking, and 20 of the directives have entered into force up to the present time. They cover commodities and product groups such as low-voltage equipment, toys, simple pressure vessels, electromagnetic compatibility, gas appliances, personal protective equipment, machinery, medical devices, non-automatic weighing instruments, telecommunications terminal equipment, hot-water boilers, civil explosives, lifts and recreational crafts.

To align with the acquis, Law 4703 on the 'Preparation and Implementation of Technical Legislation on Products', published in 2001, entered into force in January 2002, and it has been supplemented by secondary legislation. This greatly enhanced harmonisation works, as it provides the legal basis for harmonisation with the EC legislation. It defines the principles for product safety and for implementation of the old and new approach directives, including the conditions for placing products on the market; the obligations of the producers and distributors, conformity assessment bodies, and notified bodies; market surveillance and inspection; withdrawal of products from the market; and notification procedures. ${ }^{36}$ The legislation on market surveillance, the use and affixing of the CE conformity mark, working principles and procedures for the conformity assessment bodies and notified bodies and notification procedures between Turkey and the EU for technical regulations and standards, which apply to the non-harmonised regulated area, entered into force during $2002 .{ }^{37}$

\section{(i) Quality infrastructure}

In the $\mathrm{EU}$, national quality infrastructures are critical to the free circulation of goods in the Single Market. Turkey, as a member of a customs union with the EU

\footnotetext{
${ }^{36}$ Law 4703 is based on Council Directive 92/59/EEC on general product safety, Council Regulation $85 / \mathrm{C} 136 / 01$ on the new approach to technical harmonisation and standards and the Council resolution of December 1989 on the global approach to conformity assessment.

37 The legislation on market surveillance was prepared using Council Directive 92/59/EEC on general products safety, the Council resolution of December 1989 on the global approach to conformity assessment, Council Directive 88/378/EEC on the approximation of the laws of the Member States on the safety of toys and the European Commission (2000). The legislation on working principles and procedures for the conformity assessment bodies and notified bodies was prepared using the material in Chapter 6 of the European Commission (2000). The legislation on the use and affixing of the CE conformity mark is based on Council Decision 93/465/EEC on the modules for the various phases of the conformity assessment procedures and the rules for the affixing and use of the CE conformity marking. Finally, the legislation on notification procedures between Turkey and the EU for technical legislation and standards is based on Council Directive 98/34/EC, which outlines a procedure for the provision of information in the field of technical standards and regulations, and the relevant section of Decision 2/97 of the EC-Turkey Association Council.
} 
and as a candidate country, must align its national quality infrastructure with the European one. It has to complete the establishment of the so-called quality infrastructure, a generic term encompassing the operators and operation of standardisation, testing, certification, inspection, accreditation and metrology. Products manufactured in Turkey must satisfy the same requirements prevailing in the EU, and conformity to these requirements must be demonstrated in the same way and according to same the principles. Furthermore, it is important to create confidence on an international level in the testing, inspection and certification bodies in Turkey and to create reliability in the tests they perform and in the certificates they issue.

After the formation of the customs union in 1995, private conformity assessment bodies started to invest in Turkey in order to provide international certificates and markings such as the ISO 9000 series and CE marking for Turkish producers. The Turkish Accreditation Body (TURKAK), founded in 1999, started accepting accreditation applications for conformity assessment bodies in 2001..$^{38,39,40}$ The relevant ministries are responsible for appointing notified bodies in their field of competence. These authorities work in cooperation with TURKAK to assess the capacity of the notified bodies, or accept those that are to be notified to the European Commission. In particular, the Ministry of Industry and Trade, the Ministry of Labour and Social Security, the Ministry of Health, the Ministry of Public Works and Settlements, the Undersecretariat for Maritime Affairs and the Telecommunication Authority have established cooperation protocols with TURKAK in this context. In 2002, TURKAK became a full member of the European Co-operation for Accreditation (EA). However, becoming a member of an international organisation is not sufficient to achieve international recognition of accreditation certificates, as an accreditation body must also be a signatory to specific multilateral agreements (MLAs) with other accreditation bodies.

In the past, the relatively large Turkish firms wishing to obtain CE marking for products exported to the EU market contacted the local subsidiaries of the European notified bodies that used their European laboratories for testing.

\footnotetext{
38 The legal framework for accreditation consists of Law 4457 on the establishment and tasks of the Turkish accrediting agency of 1999.

${ }^{39}$ Note that with the increase in the number of conformity assessment bodies, two associations were established: Turkish Calibration and Experiment Laboratories Association (TUKLAB) and Association for Conformity Assessment (UDDer). While TUKLAB aims to improve the coordination and cooperation between Turkish laboratories and provide support for its members in accreditation and certification processes, UDDer aims to serve as a platform in which the above-mentioned stakeholders can effectively cooperate in tackling problems related to the conformity assessment sector.

40 The legal framework for conformity assessment in Turkey consists of general provisions covered by Articles 7, 8 and 9 of Framework Law 4703 relating to the preparation and implementation of technical regulation on products, published in 2001. Detailed principles can be found in the implementing Regulation on Conformity Assessment Bodies and Notified Bodies.
} 
However, for other Turkish companies, this process was expensive and slow. The small and medium-size enterprises (SMEs) that export products to the EU found it particularly difficult to pay the high costs. ${ }^{41}$ In Turkey, marking and certification parallel to the EU system were implemented only in the automotive sector, which is subject to the old approach directives. ${ }^{42}$ In addition, Turkey has long suffered from a lack of certification bodies. ${ }^{43}$ Although Turkey opened up the certification, testing and calibration market to other actors, Turkish firms were reluctant to enter the market for conformity assessment bodies as long as uncertainties prevailed regarding the acceptance of notified bodies by the European Commission.

In April 2006, TURKAK signed four out of seven multilateral agreements (MLAs) with EA members. These four MLAs cover the areas of test laboratories, calibration laboratories, quality systems management certification bodies and inspection bodies. Hence, certificates issued by all test, calibration, quality systems management and inspection bodies accredited by TURKAK have been recognised within the EU since April 2006. With the signing of the remaining three MLAs in 2008 TURKAK's full international recognition has been completed. These three MLAs are those for product certification, personnel certification and environmental management systems certification. Finally, we note that the right of Turkey to assign Notified Bodies was officially recognised by the EU by virtue of the Association Council Decision No. 1/2006. ${ }^{44}$ Thereafter Turkish authorities have assigned a number of Turkish Notified Bodies for several New Approach Directives. ${ }^{45}$

\footnotetext{
${ }^{41}$ According to the World Bank (2005), the certification of organic nut production in Moldova exported to Germany must be renewed every six months, and each visit from an international certifying company costs US $\$ 5,000$ plus US $\$ 2,000$ per production test - once before processing and once after processing. This can amount to $\$ 18,000$ per year, which is a heavy burden for firms in an economy such as Moldova, a small economy trying to compete in international markets.

${ }^{42}$ Istanbul Technical University does automotive testing under the authorisation of the Ministry of Industry and Trade, and it performs acoustic, emissions and other tests. The Turkish Standards Institute, Tofaş-Fiat and Ford-Otosan also have engine and emissions test facilities; Seger has an audible warning devices laboratory; Tam-Test is implementing testing and certification in the case of agricultural tractors; Fren Teknik has test facilities for brakes; and Brisa has a pneumatic tyres laboratory. Turkey is implementing all relevant automotive EC directives via these facilities. We note that for automotive products, the 'e' sign verifies conformity. Crash tests, electromagnetic compatibility (EMC) and other tests on complete cars are largely conducted abroad. The National Metrology Institute was able to run the EMC tests on vehicles. It has calibration laboratories in mechanics, physics, electricity, ionising radiation and chemicals. The laboratories under construction include EMC, acoustics and liquid flow.

43 See European Committee for Standardisation (2003).

44 The Association Council Decision (ACD) No. 1/2006 has been put into force on 15 May 2006 on the implementation of Article 9 of the 1/95 ACD. It regulates the rules and procedures on the allocation of identification numbers to the Turkish notified bodies.

45 The six Turkish Notified Bodies recognised by the EU are

(i) Turkish Standards Institute (Lifts (95/16/EC), Construction Products (89/106/EEC), Appliances burning gaseous fuels (90/396/EEC), and Pressure equipment (97/23/EC)),
} 
Over time, competition among potential Turkish notified bodies will ensure lower costs for conformity assessment. The expense, time and unpredictability incurred in obtaining approvals will then be reduced by having products evaluated in Turkey. These savings can be particularly important when rejection of products in the EU can create delays and necessitate additional shipping or other costs. In addition, the SMEs can benefit from procedures in which all testing and certification steps are carried out locally at lower costs. Turkish firms, and in particular the SMEs, can then be expected to increase their competitiveness in the EU market, and more and more Turkish firms can be expected to participate in the free circulation of goods between Turkey and the EU.

Finally, note that the Turkish National Metrology Institute (UME) was founded in 1992, as part of the Scientific and Technological Research Council of Turkey (TUBITAK). The objectives of the UME are to: (i) establish and maintain national measurement standards in accordance with the International System of Units; (ii) ensure the traceability of national measurement standards to international standards; (iii) establish a national measurement system and provide services to the laboratories within this system in terms of calibration, training, consultancy and other mechanisms; (iv) ensure the suitability of the laboratories that apply to join the Turkish Calibration Service and organise their accreditation; (v) contribute to research and development in the areas of measurement techniques, calibration and basic metrology at the international level; (vi) develop high-technology products and disseminate them via its developed infrastructure; (vii) increase the quality of products produced in Turkey by providing the measurement infrastructure through the national measurement system; and (viii) represent Turkey at an international level in the field of metrology.

The above considerations reveal that, as of 2008, there is a relatively wellfunctioning quality certification system in place in Turkey, comprising the accreditation agency TURKAK, the National Metrology Institute UME, and the Turkish Standards Institute TSE, which is explained in more detail in the following. Because the transposition of harmonised European legislation into Turkish national legislation is nearing completion, what is needed as a last step is the establishment of a soundly functioning market surveillance system with improved administrative and technical infrastructure.

(ii) Turkish Cement Manufacturers Association (Construction Products (89/106/EEC)),

(iii) Turkish Lloyd Foundation (Appliances burning gaseous fuels (90/396/EEC), Pressure equipment (97/23/EC), and Recreational craft (94/25/EC)),

(iv) MEYER (Appliances burning gaseous fuels (90/396/EEC), and Pressure equipment $(97 / 23 / \mathrm{EC}))$,

(v) Chamber of Mechanical Engineers (Lifts (95/16/EC)), and

(vi) Turkish Ready Mixed Concrete Association (Construction Products (89/106/EEC)). 


\section{(ii) Market surveillance}

The legal basis for market surveillance activities consists of Law 4703 on the 'Preparation and Implementation of Technical Legislation on Products' of 2001, the 'Regulation on Market Surveillance of Products' of 2002 and specific product legislation and administrative legislation by public authorities, in the form of circulars or communiqués. The Framework Law obliges producers to put on the market only safe products, and authorises public authorities to devise and implement product-specific legislation. Even if this legislation lacks in providing for complete safety, the related authority is still bound to monitor for complete product safety with respect to its legally-established competency area. The law leaves detailed procedures and principles of market surveillance to the Regulation on Market Surveillance. In addition, each competent authority may lay down detailed procedures for its market surveillance activities in a specific legislation, defining the duties and responsibilities of the inspectors and the procedures and principles for market surveillance. In 2004, a communiqué was published in order to provide for a standard form to be used by all market surveillance authorities in registering the data collected during market surveillance.

There are 10 public authorities responsible for market surveillance and one coordinating body, which is the Undersecretariat for Foreign Trade. The public authorities are the Ministry of Industry and Trade, the Ministry of Health, the Ministry of Public Works and Settlement, the Ministry of Labour and Social Security, the Telecommunications Authority, the Ministry of Environment and Forestry, the Ministry of Agriculture and Rural Affairs, the Undersecretariat of Maritime Affairs, the 'Tobacco, Tobacco Products and Alcoholic Beverages Market Regulatory Authority' and the 'Energy Market Regulatory Authority'. An important role in the execution of market surveillance is played by the regional and provincial offices of most of the public authorities distributed all over Turkey. The provincial offices have different executive tasks, such as inspection and sampling of products and reporting of results, dealing with consumer complaints and advising the public and businesses.

For the coordination of market surveillance activities of the different public authorities, the Coordination Board on Market Surveillance was established in 2002 and is composed of members of the market surveillance authorities plus two members from the Ministry of Culture and Tourism and the Ministry of Transportation. The Board, which has no executive power, is chaired by the Undersecretariat for Foreign Trade.

As emphasised in a report prepared for the Undersecretariat for Foreign Trade (2008a), market surveillance in Turkey faces serious problems. It is emphasised that for a large percentage of consumer products, there is no market surveillance at all; the system is fragmented and in fact invisible; there is a substantial risk of conflict of interests; the activities are mainly focused on administrative issues, 
not on the safety of products, and have low priority as well; in most inspections the compliance with the General Product Safety Directive of the EU is absent and the enforcement by inspectors is hampered by logistic problems, lack of power and lack of experience. Thus, the report notes that the present system of market surveillance in Turkey is incomplete, ineffective and inefficient. ${ }^{46}$

Recently, a new draft law has been prepared for market surveillance. It will take into account the latest version of the general product safety directive (2001/95/EC). This draft law, called the 'Product Safety Law', will cover provisions related to mutual recognition, unregulated areas and the areas included in Law 4703, such as new and classical approaches, notified bodies and market surveillance in some detail.

\section{(iii) Standardisation}

The Turkish foreign trade regime concerning technical regulations and standardisation was originally published in 1995 by the Undersecretariat for Foreign Trade as the 'Ministerial Decree on the Regime Regarding Technical Regulations and Standardisation for Foreign Trade' and supplementary legislation. This regime has been amended by Ministerial Decree No. 2005/9454 for Technical Regulations and Standardisation for Foreign Trade, a Regulation and related Communiqués. The Decree covers the technical regulations, standards, conformity assessment and inspections to which import and export products are subject, the obligations of the importers and exporters, the powers and the obligations of the customs authorities and related authorities, the sanctions to apply and the notifications related to these issues. The decree also defines the administration competent for issuing technical requirements for imports. Therefore, by force of this Decree and its implementing provisions, certain mandatory

\footnotetext{
46 The report notes that in Turkey for a great part of product groups, there is hardly any sampling and analysis and that a large number of consumer products are not monitored at all. There is limited laboratory capacity, and this capacity is used only partially. Warnings and fines are seldom imposed, and withdrawals and recalls occur even less often. The market surveillance system is fragmented, both on a national level and even within authorities, and it is too complicated. Each authority has its own inspection body or even several bodies per type of product, and there are no obvious transverse links between the different inspection bodies. Policy at each authority is top-down, so that management and execution are determined centrally, with weak influence from the regions. As a result, the overall coordination between the market surveillance activities is fragile. Furthermore, market surveillance is usually based on conformity and consists of checks of CE marks and documents. There are not checks on safety, and pro-active risk assessment is generally lacking. Although effective market surveillance requires powerful inspectors, who are authorised to make quick decisions at the place of inspection according to the risk occurred, inspectors are not in a position to fulfil these requirements. They are reluctant to make decisions, as the legal status of the inspectors is not sufficiently regulated. In addition, there is no implementing authority for the non-harmonised consumer products, and market surveillance activities in the case of these products are not carried out at all. Finally, the report stresses that there are no binding or result-oriented agreements on activities such as the number of inspections to be carried out, and there is no separate budget for samples or for lab analysis.
} 
standards are still in place. On the other hand, the Regulation and the Communiqués are amended every year, except for the Communiqué on the Imports of CE Marked Products. ${ }^{47}$ Furthermore, the Regulation is related to the controls of the agricultural products to be exported within the scope of the standards mandated in exports, and it determines the framework of the import controls, which are regulated by communiqués in more detail. ${ }^{48}$

Although, in principle, standards are voluntary in Turkey, in the absence of a proper market surveillance system, the technical ministries and the Undersecretariat of Foreign Trade have turned the process of standardisation and licensing before production into a mandatory regime for both domestic and imported products, in order to protect the market and the consumers. This pre-market control system gave the Turkish Standards Institute (TSE) a great deal of power. ${ }^{49}$ According to the European Committee for Standardisation (2003), the TSE has misused its power in several cases of imports and has created TBTs. The TSE asked for the technical files of the imported products when they entered the Turkish market, and the processing of the files usually took a long time. There were also cases in which products bearing the CE marking were asked to be further inspected.

Since 2004, products covered by directives on toy safety, medical devices, active implantable medical devices, low-voltage electrical equipment, electromagnetic compatibility, machinery and construction products have not been subject to mandatory controls when imported and used in the internal market. With the Communiqué on Standardisation for Foreign Trade No. 2008/1, 190 commodities classified in the 12-digit harmonised system of tariff classification (HS) are, as of 2008, subject to inspection by the TSE. ${ }^{50}$ All of these commodities refer to those in the unregulated area. The inspections are carried out in respect of minimum standards of health, safety and protection of the environment, providing adequate information to consumers.

Because of recent developments in the harmonisation works, the number of standards that are mandatory for the domestic market as well as for imports has substantially decreased, and it seems that the TSE's monopoly as an active player of the mandatory standards controls is ending. Thus, Turkey has replaced all national standards with EU and international standards and signifi-

\footnotetext{
47 The Communiqué on the Imports of CE Marked Products was published in the Turkish Official Gazette on 14 February 2004, No. 25373. The Regulation and the Communiqués for 2008 were promulgated in the Turkish Official Gazette on 31 December 2007, No. 26743.

${ }^{48}$ For more information on legislative alignment, see the website of the Undersecretariat for Foreign Trade: www.dtm.gov.tr.

49 The Turkish Standards Institute (TSE) was established in 1954 to draft standards for all kinds of products and services. The TSE is responsible for issuing and implementing technical standards. So far, it has transposed close to 90 per cent of the CEN and CENELEC standards. The TSE is a member of the ISO and IEC as well as an affiliate member of CEN and CENELEC.

${ }^{50}$ See the Official Gazette of 31 December 2007 and No. 26743.
} 
cantly reduced the number of mandatory standards applied to imports; this reduction brings Turkey close to having an EU-compatible control mechanism on imports from third countries. However, as of 2008, a remarkable difference exists between the intensity of controls over imported products and domestic products in Turkey. Since import control focuses on the surveillance of goods to be imported from third countries, and local products are expected to meet the same requirements as imported ones, the same directives could apply, in principle, for the surveillance of all products, whether imported or domestically produced. An obvious advantage of combining import control with the surveillance of the domestic market is that the available personnel capacity can be employed on a broader scale, and cooperation with customs can be smooth and uniform.

\section{CONCLUSION}

The Trade Policy Review: Turkey 2007 is a comprehensive review of traderelated policies in Turkey. It has provided a wealth of information about the economic developments in Turkey in general, and the Turkish trade policies in particular. The well-developed format of Trade Policy Reviews (TPRs) successfully discerns what has been improved and what sort of issues remain.

As emphasised in WTO (2008), Turkey is pursuing a strategy of trade liberalisation through negotiations at the multilateral, regional and bilateral levels. It is actively participating in the Doha Development Agenda. Nonetheless, Turkey's membership in several arrangements makes its trade regime complex and seemingly difficult to manage. It is stressed that further multilateral trade liberalisation could reduce the need for preferential trade arrangements.

As of 2009 Turkey has a very liberal trade regime for industrial goods. Although tariffs for Turkey are largely a non-issue in the non-agricultural sector, free trade in industrial goods between Turkey and the EU could still not be established mainly because of NTBs and, in particular, because of the various problems faced in the elimination of TBTs.${ }^{51}$ The establishment of the quality

\footnotetext{
51 The reasons for the non-elimination of TBTs between Turkey and the EU are various. Firstly, the task itself is a very challenging one. Secondly, the framework law and the associated legislation, which is the basis for the work of harmonisation of the EU's technical regulations, was put into effect only in January 2002, seven years after the formation of the customs union. Thereafter the adaptation process for both the new and classical approach regulations has accelerated and a large number of related regulations were adopted by Turkey. This time, however, Turkey faced another difficulty. There was not a mechanism between Turkey and the EU similar to the one provided by the 'EFTA Surveillance Body', which evaluates the regulations prepared by the EFTA countries and ascertains the acceptability of these regulations by the EU. Fourthly, the number of personnel in the responsible ministries and governmental bodies who were fluent in English and trained in
} 
infrastructure turned out to be a lengthy and complex process, as, until the formation of the customs union with the EU, Turkey had no such infrastructure nor did it have the required technical knowledge. Establishing public awareness of the problem, acquiring the necessary knowledge and establishing the infrastructure took some time. The development of market surveillance structure as in the EU turned out to be even more challenging than establishing the quality infrastructure. The reasons are again various. A successful consumer product safety-related market surveillance system requires independence, visibility, uniform surveillance policy, uniform enforcement policy, integration of market surveillance and import controls, stronger regions, more acting power for inspectors, and sufficient technical infrastructure. ${ }^{52}$ Unfortunately, the Turkish system does not meet these conditions. The continuation of these problems has adversely affected the elimination of TBTs in trade with the EU.

The costs of adjustment related with the elimination of TBTs in trade with the EU has been substantial for the Turkish public sector. These costs involve the costs associated with the adoption of technical legislation equivalent to that of the EU; the establishment of institutions required for efficient functioning of quality infrastructure as in the EU such as TURKAK, the National Metrology Institute, and market surveillance authorities; the training and employment of sufficient numbers of suitably qualified and experienced staff with the necessary professional integrity to be employed in those institutions; and the acquisition of the technical infrastructure (laboratories, cars, fuel) required for efficient functioning of the system. However, the task is not complete. Additional adjustment costs have to be incurred by the public sector. Turkey has incurred these costs with the hope of becoming a full member of the EU, and the associated costs were considered as the unavoidable costs of the EU accession. But as the chances of EU membership have decreased over time, doubts have arisen in Turkey over whether the strategy adopted by the country for the elimination of TBTs has in fact been the right strategy.

\section{REFERENCES}

Baldwin, R. E. (2001), 'Regulatory Protectionism, Developing Nations and a Two-tier World Trade System', Brookings Trade Forum, 3, 237-80.

Delaney, H. and R. van de Zande (2000), 'A Guide to EU Standards and Conformity Assessment', National Institute of Standards and Technology Special Publication 951 (Gaithersburg: NIST).

European Commission (1997), 'Accreditation and the Community's Policy in the Field of Conformity Assessment', CERTIF 97/4 - EN Rev. 2 (Brussels: European Commission).

matters related to TBTs was insufficient. Finally, financial resources provided for harmonisation of technical legislation were limited.

${ }^{52}$ See Undersecretariat for Foreign Trade (2008b). 
European Commission (1998), Dismantling of Barriers: Technical Barriers to Trade, The Single Market Review, Subseries III: Volume I (Luxembourg: Office for Official Publications of the European Communities (OOPEC)).

European Commission (2000), Guide to the Implementation of Directives based on the New Approach and the Global Approach (Brussels: European Commission).

European Commission (2007), 'The Internal Market for Goods: A Cornerstone of Europe's Competitiveness', Communication from the Commission to the European Parliament, the Council and the European Economic and Social Committee, COM(2007)35 final (Brussels: European Commission).

European Committee for Standardization (2003), Support to the Quality Infrastructure in Turkey: Country Report 2003 (Brussels: CEN).

Howarth, P. and F. Redgrave (2003), Metrology - In Short, document prepared for the European Commission.

Izmen, Ü. and K. Y1lmaz (2009), 'Turkey's Recent Trade and Foreign Direct Investment Performance', Economic Research Forum Working Paper 0902 (Istanbul: TÜSIAD-KOÇ University).

Kaminski, B. and F. Ng (2007), 'Turkey's Evolving Trade Integration into Pan-European Markets', Journal of International Trade and Diplomacy, 1, 35-103.

Maskus, K. E. and J. S. Wilson (2001), 'A Review of Past Attempts and the New Policy Context', in Quantifying the Impact of Technical Barriers to Trade: Can it be Done? Keith E. Maskus and John S. Wilson (eds.), (Ann Arbor: University of Michigan Press).

National Academy of Sciences (1995), Standards, Conformity Assessment, and Trade: Into the 21st Century (Washington, DC: National Academy Press).

Organisation for Economic Co-operation and Development (2006), 'OECD's FDI Regulatory Restrictiveness Index: Revision and Extension to More Economies', Working Paper on International Investment No. 2006/4 (Paris: OECD).

Stephenson, S. M. (1997), 'Standards and Conformity Assessment as Non-tariff Barriers to Trade', Policy Research Working Paper 1826 (Washington, DC: World Bank).

Sykes, A. O. (1995), Product Standards for Internationally Integrated Goods Markets (Washington, DC: Brookings Institution).

Undersecretariat for Foreign Trade (2008a), 'Analysis Report on Market Surveillance System in Turkey with an Emphasis on Consumer Products "Report of the Present Situation", report prepared within the context of the Twinning Project funded by the European Commission on 'Reinforcement of Institutional Capacity for Establishing a Product Safety System in Turkey', Ankara.

Undersecretariat for Foreign Trade (2008b), 'The Way Ahead', report prepared within the context of the Twinning Project funded by the European Commission on 'Reinforcement of Institutional Capacity for Establishing a Product Safety System in Turkey', Ankara.

World Bank (2005), Global Economic Prospects 2005 (Washington, DC: World Bank).

World Trade Organization (2008), Trade Policy Review: Turkey 2007, WTO (Geneva: WTO Publications). 